\title{
Political Islam, Marriage, and Fertility: Evidence from a Natural Experiment ${ }^{1}$
}

\author{
Ozan Aksoy \\ University College London \\ Francesco C. Billari \\ Bocconi University
}

\begin{abstract}
The plethora of pathways leading to family formation decisions has made the causal assessment of the influence of politics and religion on marriage and fertility difficult. The authors exploit the unique opportunity offered by the emergence of a new political party in Turkey, and the electoral features of the country's majoritarian system, to estimate the effect of politics and religion on marriage and fertility. The AK Parti (Justice and Development Party), with an explicitly Islamist platform, won Turkish elections in 2002, taking both a pro-natalist and pro-family stance, with increasing welfare expenditures and an explicit neoliberal agenda on macroeconomic issues. The authors analyze the results of the 2004 local elections using a regression discontinuity design and show that fertility and marriage rates have been significantly higher in districts where the AK Parti won. They argue that increased local welfare provision is the main explanatory mechanism, also discussing other alternative and complementary mechanisms.
\end{abstract}

Marriage and fertility are crucial ingredients of social reproduction. Not surprisingly, therefore, they have long occupied a central role in political discourse and have at times become the direct aim of political action through

${ }^{1}$ This article benefited from comments at the 2016 AlpPop and Population Association of America Conferences and seminars at Linköping (Institute for Analytical Sociology), Leipzig (Sociology), Oxford (Nuffield College), and the University of California, Los An-

(C) 2018 by The University of Chicago. All rights reserved. 0002-9602/2018/12305-0002\$10.00 
"population policy" or "family policy." Teitelbaum defined strategic demography as the active deployment of fertility as national policy (2015). Strategic demography has been adopted by several conservative political parties (and governments), many of which have an explicit religious ideology. Still, pronatalism has roots that are generally seen as more progressive, such as in the crafting of a "democratic family and population policy" by Myrdal (1941) as a foundation for the modern Swedish welfare state.

A central issue in triggering pro-natalism is the fear of population decline as a consequence of declining marriage and low fertility (Teitelbaum and Winter 1985). This fear is not novel. Almost a century ago, Thompson (1929) identified a group of countries facing population decline as a consequence of belowreplacement fertility. Thompson's approach was not intellectually isolated. Although not always aware of one another's work, several scholars from different countries published bleak views of population decline before World War II and before the formulation of the idea of a demographic transition by Notestein (1945; Kirk 1996). The more recent emergence of sustained below-replacement fertility in several societies has contributed to producing a second wave in this debate (Kohler, Billari, and Ortega 2002; McDonald 2006; Morgan and Taylor 2006; Marshall 2015). Religion has been seen as holding a central role in the politics of "family decline" (Brooks 2002). As marriage, fertility, policies, and religion are evolving together, it is difficult to find evidence on their mutual effects. To what extent do politics and religion shape marriage and fertility trends? We address these questions by focusing on what Merton (1987) called a strategic research site: Turkey at the beginning of the 21 st century.

Turkey epitomizes the centrality of the links among religion, politics, policies, and marriage and fertility. During the 20th century, a series of successive governments implemented a modernization agenda, with an explicit emphasis on both economic development and secularization, following the basic tenets of the founder of the Turkish Republic, Mustafa Kemal Atatürk. This agenda included the reduction of gender inequalities. Turkey's fertility decline has been consistent with standard theories on family and fertility change

geles (California Center for Population Research). We thank Evrim Altintaş, Richard Breen, Duncan Gallie, Nan Dirk de Graaf, John Goldthorpe, Patrick Heuveline, Jennifer Johnson-Hanks, Dave Kirk, Melinda Mills, Şafak Müderrisgil, Turkay Nefes, Berkay Özcan, Alberto Palloni, Serdar Polat, Anne Pebley, and the AJS reviewers. Aksoy acknowledges support from the Netherlands Organization for Scientific Research (grant 446-13-004). This project has received further funding from the European Research Council under the European Union's Horizon 2020 research and innovation program (grant 694262), project DisCont-Discontinuities in Household and Family Formation. Direct correspondence to Ozan Aksoy, Department of Social Science, UCL Institute of Education, University College London, London WC1H OAL, United Kingdom. E-mail: ozan.aksoy@ucl.ac.uk 
(Cleland and Wilson 1987; Kirk 1996), and the replacement level was reached in the early 2000s. However, the results of the 2002 Turkish political elections marked a political, and religious, turning point. In these elections, the AK Parti and its leader, Recep Tayyip Erdoğan, won on a platform that has emphasized Islamism and used political discourse in defense of traditional family and fertility values. During the following decade, the AK Parti's platform translated into political actions, including, as we will see more in detail, promarriage and pro-natalist welfare policies deployed at the local level, in a way that is consistent with the party's simultaneously neoliberal and religious platform. This wave of policies has been defined by Altık (2013) as "reproductive governmentality," echoing Teitelbaum's notion of strategic demography. Under AK Parti's rule, local welfare provision has been expanded, and this expansion was starker in the areas in which it first came into power. After 2002, fertility decline has stalled and subsequently even slightly reversed. This reversal has clear political significance, as we discuss in the next section. In 2015, the Turkish Statistical Institute (TurkStat) emphatically announced that fertility had climbed back again above the replacement level in the previous year (a total fertility rate of 2.17 in 2014). ${ }^{2}$

In this article, we build three data sets on Turkey by linking electoral (and socioeconomic) data at the local level with family and fertility outcomes. We then exploit the features of Turkey's electoral system to apply a regression discontinuity design (RDD) to estimate the impact of AK Parti rule on Turkish marriage and fertility behavior. The majoritarian features of the Turkish election system allow us to use RDD (Thistlethwaite and Campbell 1960; Imbens and Lemieux 2008; Lee and Lemieux 2010) to compare districts that at the margin only differ by the ruling party, as a natural experiment. RDD has very favorable properties, which allow for a clear identification of causal effects. Despite these favorable properties, RDDs are still underutilized in sociology (Gangl 2010). Using RDD, we are able to document the causal effect of a locallevel turning point, the AK Parti's rise in power, on marriage and fertility. Our results are generally consistent across the three data sets.

We find that AK Parti's rule has the effect to increase (or to halt the decrease of) marriage and fertility rates. As our preferred explanation on the effects of politics and religion on marriage and fertility in Turkey runs through the provision of local welfare, we also test the potential heterogeneity of causal effects, showing that the effect on fertility is larger in poorer regions. We test for the effects of alternative and complementary causal path-

\footnotetext{
2 "While the total fertility rate was 2.10 children according to the revised 2013 data, this rate was 2.17 children in 2014. It means that a woman gave approximately 2.17 live births during her reproductive life. This case showed that the replacement level of fertility was exceeded" (Turkish Statistical Institute, press release no. 18621, April 17, 2015; see http://www.turkstat.gov.tr/PreHaberBultenleri.do?id=18621). Still, vast heterogeneity persists in age at marriage and total fertility rates at the subnational level.
} 
ways, running through economic development, religion-based changes in marriage and fertility preferences, immigration, and infant mortality.

The remainder of this article is structured as follows. We first discuss our strategic research site, Turkey, illustrating both general societal and political change up to the end of the 21 st century and changes, including policies, introduced during the first period of AK Parti's rule. This leads us to formulating our main testable hypotheses, that is, that AK Parti's rule had the effect of increasing (or halting the decrease of) marriage and fertility in areas in which it first came into power and that this effect is mainly linked to the increased provision of welfare at the local level. We then introduce the RDD method and the data and measures we use. After presenting the results of our analyses, and discussing alternative and complementary mechanisms, we then conclude by summarizing our contributions and discussing our key findings.

\section{TURKEY CIRCA BEGINNING OF THE 21ST CENTURY}

Turkey has gone through state-controlled processes of secularization and modernization since its inception, in 1923. Describing Turkey's modernization process at the end of the 1950s, Bellah (1958) emphasized the relevance of Ziya Gökalp (a sociologist of Durkheimian influence) in shaping the "Kemalist" project (Mustafa Kemal Atatürk was Turkey's first president, until his death in 1938). Gökalp championed Turkish nationalism as the cultural foundation for the new Turkey, as "the referent for all symbols of ultimate value in society itself" (Bellah 1958, p. 3). Family issues were central, as one would expect given the Durkheimian framework, in this nationalistic modernization process (Kavas and Thornton 2013). The geopolitical role of Turkey as a "bridge" between Europe and the Middle East pushed the country to join North Atlantic Treaty Organziation in 1952, and its economic development was recognized as early as 1962, when Turkey joined the Organization for Economic Cooperation and Development. Three interrelated developments at the beginning of the 21 st century make the Turkish case a strategic one for our purposes: the end of the fertility transition, the end of the state-controlled modernization process and the rise to power of the Islamist AK Parti, and the development of explicit welfarebased pro-natalist and pro-marriage policies deployed at the local level consistent with the religious inspiration of the AK Parti.

First, Turkey reached the end of its fertility transition at the end of the 20th century, with the total fertility rate reaching the replacement level in 2003, despite previous accounts that mentioned Turkey as a case of a fertility transition "stalled" around a rate of 2.5 (Bongaarts 2006). ${ }^{3}$ Still, fertility differ-

\footnotetext{
${ }^{3}$ Fertility rate data available from TurkStat, http://www.turkstat.gov.tr/Prelstatistik Tablo.do?istab_id=1592; accessed December 21, 2017.
} 
entials estimated through Demographic and Health Surveys (DHS) for 2008-13 reflect traditional heterogeneity, with strong regional and rural/urban differences, as well as differences with respect to education and wealth (Hacettepe University Institute of Population Studies 2014). Again using DHS, an indicator of "total wanted fertility" that excludes unwanted children locates desired fertility at 1.9 children per woman (as opposed to the 2.3 that is actually recorded for women who participated in the survey). While indicators on fertility desires should not be directly taken as indicators on the intentionality of reproduction (Johnson-Hanks 2007), they might be indicative of the convergence to values around replacement that is typical of many Western societies (Goldstein, Lutz, and Testa 2003). In particular, there has been a substitution in the values attributed to children, from the material/economic dimension to the psychological dimension that is also typical of posttransitional societies (Kagitcibasi and Ataca 2005). While during this period age at first marriage has shifted upward, marriage in Turkey remains almost universal, with the proportion of women never married by age 45-49 at most 3\% in 2013 (Hacettepe University Institute of Population Studies 2014).

Second, after decades of explicitly state-led secularization, Turkey shifted to an elected government run by the AK Parti, which emerged from a tradition of Islamic-oriented parties that had challenged the secular nature of previous governments (Mecham 2004; Özbudun 2006). The victory of the AK Parti was not completely unexpected, as the Kemalist modernization project contributed to the creation of an urbanized secular cleavage, with a vast majority of the population remaining poor and marginalized (Yavuz 1997, 2000). Political Islam gained power among the excluded cleavages with its "prosperity maximization/democracy" discourse (Yavuz 1997; Turan 2007). While the state-controlled modernization process had been challenged by a prosperity maximization/democracy paradigm pushed by religiously motivated political movements, it has been restored through several military interventions (Turan 2007). The AK Parti's victory in the 2002 general elections, right after the 2001 economic crisis, signaled the end of state-controlled modernization-our main turning point. This revival of political Islam was in fact, and quite remarkably, predicted by Bellah more than half a century earlier: "it is too soon to say that it [the differentiation between the levels of religion in Turkey and social ideology] has been entirely accomplished" (1958, p. 2).

Third, the government has openly adopted pro-natalist and pro-marriage views - a clear step toward "strategic demography." Historically, Turkey followed pro-natalist policies between 1923 and 1960 (Yüksel 2013). The founding of the State Planning Organization, after the 1960 military coup, marked a policy turn. All of the five-year plans from 1960 to 2007 stressed the control of population growth as a means to facilitate economic development (Yüksel 2013). The Ninth Development Plan prepared under the rule of the AK Parti 
for 2007-13 was a turning point, mentioning for the first time challenges related to reproductive health and population aging and calling explicitly for a return to pro-natalist policies. In particular, the prospects of population aging contributed to driving this agenda. In 2012, Ambassador Apakan, the permanent representative of Turkey to the United Nations in New York, depicted a grim picture of fast population aging in emerging economies and developing countries, as Turkey was shown as the "second-fastest aging country in the world." "The main leader of AK Parti, Recep Tayyip Erdoğan, in his roles as prime minister and president of Turkey made explicit pro-natalist and promarriage remarks. In 2009, he declared: "Every family should have at least three children, before it is too late. The more we grow, the stronger we will become, be assured." In 2014 he stated, "Don't delay marriage. While you are studying, or as soon as you graduate, take care of it. Don't be too picky, if you are too picky, you will leave the rose garden empty-handed," and "We need this (a younger population) to take Turkey above the level of modern civilizations. In this country opponents have been engaged in the treason of birth control for years and sought to dry up our generation." AK Parti's approach has not only been mere political rhetoric. Since 2002, the government has launched a wave of social and economic assistance, explicitly targeting marginalized families, young couples, mothers, and children (Metin 2011). Finally in January 2015, the AK Parti announced a new Program for the Protection of the Family and Dynamic Population Structure. The program includes several incentives and policies aimed to increase fertility and facilitate a baby boom (Yüksel 2013).

The roots of AK Parti's strong pro-natalist stance can be found in Turkey's traditional political Islam, particularly Necmettin Erbakan's National Order Party (MNP). The MNP was founded in 1970 as Turkey's first explicitly Islamist political party and was shut down by the constitutional court in 1971 following the military coup in the same year. The MNP strongly opposed the anti-natalist population policies of the 1960s. The MNP saw those policies as a product of an "international conspiracy" that ultimately aimed to "morally invade" the country by "stunting its national development" (Güriz 1971,

\footnotetext{
${ }^{4}$ See http://www.cfr.org/content/publications/attachments/Apakan-Intro-and-Comments .pdf (October 10, 2009).

${ }^{5}$ See https://www.ntv.com.tr/turkiye/erdogan-is-isten-gecmeden-en-az-3-cocuk,ZE QhCeWHVkS061EDhd72Ng (October 10, 2009; in Turkish).

${ }^{6}$ See http://t24.com.tr/haber/evliligi-geciktirmeyin-turgev-bu-konuda-cok-iyi-bir-ihtisas -alani,264790 (July 18, 2014; in Turkish) and http://amanpour.blogs.cnn.com/2014/11/26 /turkish-president-erdogans-sexist-remarks-reinforces-prejudices-against-women/ (November 26, 2014; in English).

${ }^{7}$ See http://www.independent.co.uk/news/world/middle-east/president-erdogan-at-couples -wedding-birth-control-is-treason-to-growth-of-turkey-9944286.html (December 22, 2014).
} 


\section{American Journal of Sociology}

p.35). ${ }^{8}$ The MNP's conspiratorial discourse and its view that links strong pronatalism with nationalist and Islamic motives bear a striking resemblance to the Erdoğan's quotes above. The main political opposition, the center-left secular Republican People's Party (CHP), remains a strong defender of the pre-AK Parti anti-natalist population policies. For example, the CHP party program proposes to increase the number of health professionals specialized in family planning, particularly in rural areas, as a means to control and assess the socioeconomic effects of population growth. ${ }^{9}$ The second largest opposition force, the far right Nationalist Movement Party (MHP), has historically opposed the 1960s population control policies (Güriz 1971). However, recent party programs of the MHP are rather silent on population issues, as they do not propose any explicit pro- or anti-natalist policies. Hence, the AK Parti's strong pro-natalist turn marks not only a historical shift in population policies that the central government has embraced but also a divergence from the contemporary views of non-Islamist opposition parties.

To understand the effects of these simultaneous changes, it is essential to go beyond the national level. In particular, the initial heterogeneity of marriage and fertility, whether the AK Parti is in power in a particular area, and the ability to transmit pro-natalist and pro-marriage policies at the local level are powerful factors that channel national-level change through the subnational level.

\section{THE WELFARE ROLE OF LOCAL AUTHORITIES AND ORGANIZATIONS}

Pro-natalism entered the political agenda as a national discourse during the reign of the AK Parti. Yet, the channels through which the AK Parti could influence reproductive behavior heavily involve local authorities and organizations, intertwining welfare policies and religious ideology. Erdoğan himself linked religion and pro-natalism in an explicit way, as in his 2016 statement: "We need to increase the number of our descendants. People talk about birth control, about family planning. No Muslim family can understand and accept that! As God and as the great prophet said, we will go this way. And in this respect the first duty belongs to mothers." ${ }^{10}$ This local propagation of this national discourse has occurred chiefly through the combination of two parallel developments: a neoliberal agenda aiming at the reduction of the role of the central government in the welfare system and an

\footnotetext{
${ }^{8}$ See Güriz (1971) for the MNP's party program and a discussion.

${ }^{9}$ For party programs, see https://www.ttb.org.tr/kutuphane/siyasi_parti_prog.pdf (in Turkish).

${ }^{10}$ See http://www.telegraph.co.uk/news/2016/05/30/family-planning-not-for-muslims-says -turkeys-president-erdogan/ (May 30, 2016).
} 
increase in the role that charities controlled by local authorities play in welfare provision.

Following the global trend started in the 1980s, and since gaining control of the central government in 2002, the AK Parti has accelerated the adoption of neoliberal-style socioeconomic policies (Buğra and Keyder 2006). Indeed, the Islamic state-restructuring project of the AK Parti was also shaped by the neoliberal agenda of the European Union, the International Monetary Fund, and the World Bank (Atasoy 2009). This neoliberal shift implied a reduction in the central government's role in providing basic social services and social security (Buğra and Keyder 2006; Celik 2010). Examples include labor market reforms (law 4857) that introduced flexible work schemes and a de-unionization of the workforce. Perhaps the most telling example of this trend is the letter that the AK Parti penned to the International Monetary Fund in 2005, stating its ultimate aim of reducing the share of the gross domestic product (GDP) deficit reserved for the social security system from $4.5 \%$ to only $1 \%$ (Celik 2010). This reduction in the central government's share in social expenditure has been counterbalanced by the expansion of a local charity-based welfare system, which relies on philanthropic and religious motives (Buğra and Keyder 2006; Celik 2010). In this system, funds raised by local organizations and municipalities are used to assist the poor and marginalized groups. Municipal governments have played a crucial role in raising funds for welfare and in its provision (Metin 2011). It has been common for district mayors and other local authorities to sit directly on the boards of trustees of social assistance and solidarity foundations, the major players in the distribution of social assistance (Dodurka 2014). ${ }^{11}$ In fact, municipalities have served as brokers in charity, by channeling funds provided by private donations. The sources of these donations have often been unclear, and there is no reliable information at the district level on the magnitude of funds used for assistance (Buğra and Keyder 2006). It is generally thought that the main body of donations has come from private businesses that secure contracts from municipal governments (Celik 2010). This system has given municipal governments considerable discretion, which has paved the way to potentially clientelist policies that have distributed social assistance in a way that maximizes the chances of reelection of the governing party (Metin 2011; Aytaç 2014).

The local welfare system has been implemented in cooperation with the central government. This agenda is explicit in the official program of the AK Parti: "Our party will enable the cooperation of the central government with local authorities, NGOs, and the private sector to increase the efficiency,

${ }^{11}$ See http://sosyalyardimlar.aile.gov.tr/sosyal-yardimlasma-ve-dayanisma-vakiflari /sydvlerin-yapisi (in Turkish). 
speed, and resource capacity of social welfare services." ${ }^{12}$ On the other side, as the former minister of justice and former vice president of the AK Parti put clearly, local authorities that do not "get along well with the central AK Parti government had a hard time having their projects approved by Ankara."13 This "synchronization" between local AK Parti municipalities and the central AK Parti government has given local AK Parti mayors a clear advantage over their counterparts of opposition parties. Moreover, the AK Parti has a strong tradition and experience in local government. As the prime example, Erdoğan himself had served as the mayor of Istanbul before founding the AK Parti and becoming the prime minister.

Two additional important characteristics have given local governments ruled by the AK Parti an advantage in mobilizing and channeling initiatives for welfare provision: an Islamic focus on motivation and mobilization and a strong emphasis on the family as the prime target of the welfare system. First, religious motivations have played a central role in welfare provision. As an example, one of the most prominent nongovernmental organizations in welfare has been Deniz Feneri (Lighthouse), an organization that uses Islamic values as primary motivations for charitable giving (Buğra and Keyder 2006). Donations made to social assistance funds in districts controlled by the AK Parti have been considered by most religiously motivated donors as zekat, a periodic charitable payment required by the Islamic law as one of the five pillars of Islam (Kocal 2014). The second important characteristic of the welfare system is particularly relevant for our analysis: a strong emphasis on the family. The official AK Parti program states: "if the Turkish society is still intact after so many problems this is because of our strong family structure." ${ }^{14}$ According to the figures published by TurkStat, since 2002 the funding for socioeconomic assistance has increased by 15 times, mainly due to this charity-based welfare system. Figure 1 shows the increase in the share of funds spent for social assistance between 2002 and 2011 relative to the GDP. A substantial portion of this welfare assistance has targeted families, mothers, young couples, and children. Mothers have received conditional training and health related (e.g., pregnancy) aids, to the extent of covering about 3 million children annually. Also, a premarriage training program has been implemented at the local level by AK Partiled municipalities. Between 2003 and 2013, 4.2 billion TL (approx. US $\$ 1.8$ billion) have been spent for housing help toward poor families. In 2005, the AK Parti also extended the coverage of a "green card," which basically en-

\footnotetext{
${ }^{12}$ See sec. 5.1 para. 3 (in Turkish) at https://www.akparti.org.tr/site/akparti/parti-prog rami\#bolum_(accessed December 21, 2017).

${ }^{13}$ See http://www.hurriyet.com.tr/yazarlar/11070235.asp (in Turkish).

${ }^{14}$ AK Parti (2015) 2002 Genel Seçimleri Beyannamesi [2002 General Election Manifesto], p.122, http://www.akparti.org.tr/upload/documents/2002-beyanname.pdf (accessed December 21, 2017).
} 
Political Islam, Marriage, and Fertility
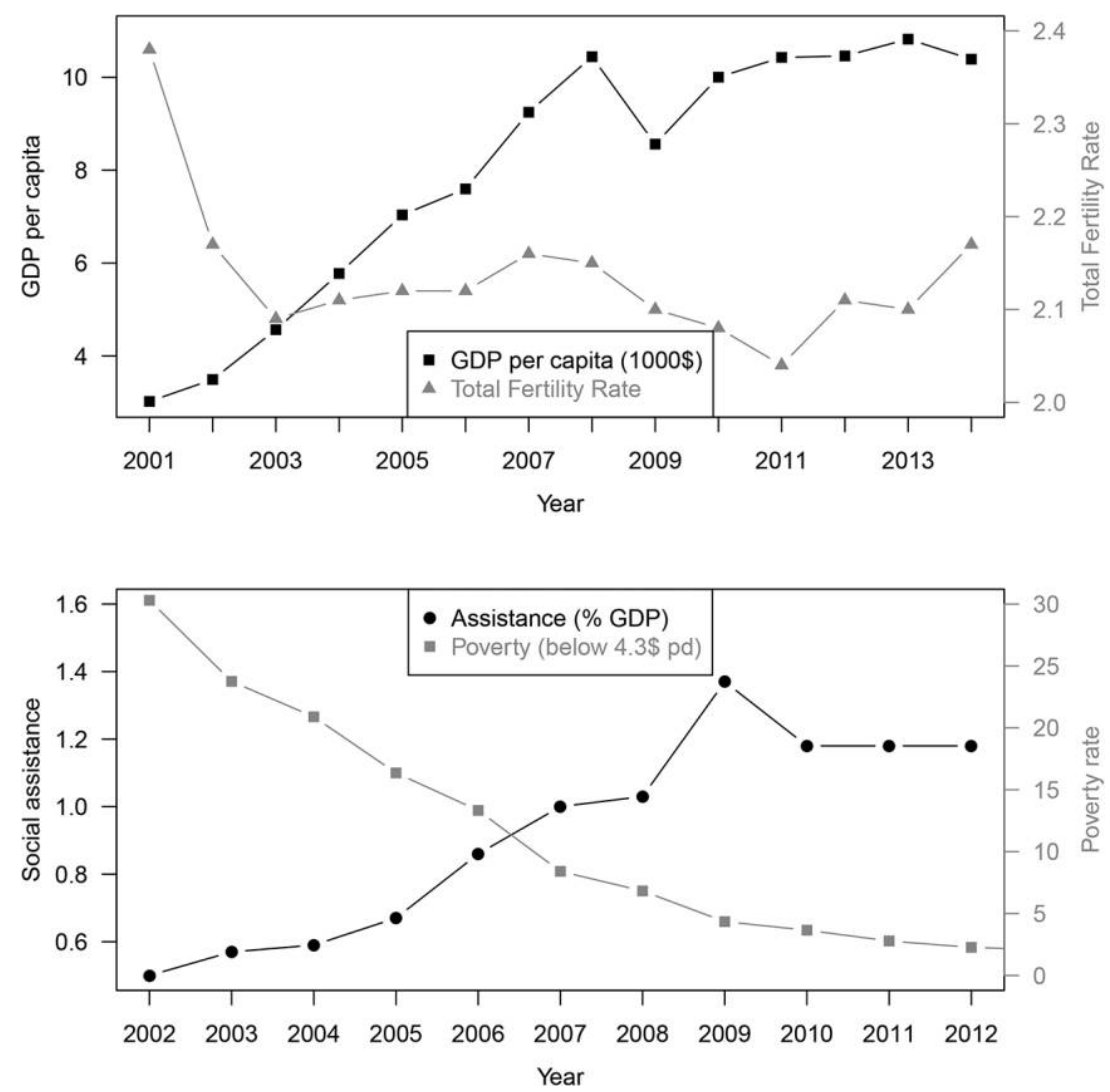

FIG. 1.-Top, per capita GDP and total fertility; bottom, total social assistance expenditure (as percentage of GDP) and income-based poverty rate (data from the Turkish Statistical Institute).

ables access to free health care for those without any formal insurance. Mainly because of this increase in social assistance, poverty has decreased substantially since 2002 (Yavuzkanat 2013). Figure 1 shows the change in annual poverty rates since 2002. The proportion of people earning under US $\$ 4.3$ per day has decreased from about $30 \%$ in 2002 to $4 \%$ in 2011 . Expenditure-based poverty rates have also decreased from $27 \%$ in 2002 to about $18 \%$ in 2009, a milder decrease due to the increase in inflation during the crisis. Unfortunately, TurkStat stopped reporting expenditure-based poverty rates after 2009.

\section{HYPOTHESES AND MECHANISMS}

Our discussion of the interplay among politics, policies, and religion within the context of Turkey shows clearly that there is an internal consistency in 
the AK Parti's strategic demography. Family and fertility are a target, both ideologically and through welfare policies, and welfare targeted to the poor is a means to consolidate political power. We will focus on the first decade of AK Parti rule, and in particular on the period that follows the local (mayoral) elections held in 2004, less than two years after the national election marking the ascent of Erdoğan to the prime ministry. We have seen that during this period at least, welfare has been provided via a charity-based system orchestrated by local governments, rather than through a national social policy implemented in a standardized way across Turkey. Organic relationships between AK Parti local governments and the national-level government, and the Islamic elements of this welfare system have given AK Parti local governments an advantage in mobilizing resources toward welfare provision and in implementing effective social policies. Therefore, our central empirical hypothesis is that local AK Parti governance has increased (or prevented the decline of) marriage and fertility rates. We will directly test this causal hypothesis, using an appropriate design that exploits the unique natural experiment given by 2004 local elections.

Our main hypothesis also resonates with previous empirical evidence on local Islamic governance in Turkey. For instance, contrary to the common belief that associates Islamic rule with undesirable outcomes for women, research has shown that local Islamic rule may, in fact, improve women's well-being on a number of dimensions. Blaydes (2014), for example, shows that women who live in areas ruled by an Islamic group in Cairo are better off with respect to several reproductive health-related outcomes than a very similar group of women who live in areas that are ruled by local strongmen. More important, using a regression-discontinuity design that is closely related to ours on the same societal setting, Meyersson (2014) shows that local Islamic rule in 1994 in Turkey has a positive causal effect on female educational attainment and on political participation in subsequent years. One way of interpreting this outcome is as follows. Local Islamic rulers who operate in countries with secular authoritarian central governments provide good local services and empower the marginalized poor and pious because in doing so they seek to "incrementally displace the state and traditional elites" (Blaydes 2014, p. 503). Nonstate service provision at the local level can be also seen as an electoral strategy that helps in winning further votes (Thachil 2011). This interpretation fits the track record of the AK Parti, too. The massive welfare spending that the AK Parti has mobilized starting from its early years, be it clientelism or genuine concern for the poor, has helped the AK Parti increase its support among the marginalized electorate and eventually secure further its control of the central government (Metin 2011). As the main mechanism we posit runs through local welfare provision and the empowerment of the marginalized poor, a related empirically testable hypothesis we state is that local AK Parti governance has increased (or prevented the decline of) 
marriage and fertility more in the poor parts of the country than in the less poor parts.

The main mechanism we posit, therefore, works mostly through lifting constraints on fertility and marriage with effective welfare policies at the local level. AK Parti's local rule can also have an effect on marriage and fertility through mechanisms that are alternative or complementary to the main one we posit. We introduce five of these mechanisms, for which we will be able to carry out empirical tests. First, there is an economic development mechanism: districts in which the AK Parti won local elections could have benefited from improved economic conditions more so than districts in which the opposition won. Although one would expect that better economic conditions would favor a decrease in fertility, as in classic demographic transition theory (Cleland and Wilson 1987; Kirk 1996), they might encourage young people to marry and perhaps even to have more children, as it is assumed in advanced societies (Gauthier 2007; Goldstein et al. 2013). Second, there is a religiosity mechanism: local AK Parti governance could have affected the religious preferences of individuals, rather than the constraints they face. This reversal in secularization would also be consistent with changing preferences toward earlier marriage and higher fertility. Third, there is a preference mechanism: local AK Parti governance may have effected fertility and marriage not through affecting constraints but through changing preferences as a consequence of AK Parti's positions.

Two other mechanisms are complementary to our main one. Our fourth is an infant health mechanism: even if local AK Parti governance may not have altered the preferences or opportunities to have more children, it could still affect children's survival chances by simply reducing infant mortality. The latter mechanism is consistent with our welfare provision narrative, although it does not posit any effects on marriage. The fifth and final mechanism is welfare migration: districts governed by the AK Parti may have selectively attracted larger families and families with children or those who intended to marry or have larger families.

\section{DATA AND METHODS}

In order to test our main hypothesis and to assess the potential mechanisms, we compiled three different data sets matching information from different sources, at different geographical levels. For the first two data sets, we matched official election results with administrative demographic statistics, data on economic well-being, and information on religious school attendance. These two data sets differ with respect to both the operationalization of our key variables and the level at which variables are measured. For the third data set, we matched official election results with microlevel data from the Turkey Demographic and Health Survey (TDHS). The compilation and use of three 
complementary data sets allows us to triangulate our findings and to conduct robustness checks. Moreover, taken together these data sets will allow us to assess the mechanisms discussed earlier. We explain below key features of these three data sets.

\section{District-Level Data Set}

To build the first data set, the district-level data set, we matched our main variables of interest (i.e., election results in 2004) with official demographic statistics published by TurkStat at the district (Ilçe) level, as well as additional demographic, political, and socioeconomic variables. Districts are clustered in larger provinces $(\dot{I} l)$. While the number of provinces has been stable at 81 since 1999, the number of districts has been increasing mildly over time, with 919 in 1999 to a maximum of 970 in 2013, mainly through new districts splitting from old ones because of increased population. Figure 2 shows a map with districts in 2007. The district is the lowest geographical and electoral unit for which TurkStat provides data on marital status and fertility. For this reason, we chose the district-level data set as the central one in our analyses.

The main variables in the data set (i.e., fertility, marriage, and election results) are computed as follows. For what concerns fertility, we use TurkStat's data from the Address Based Population Registration System (ABPS). The ABPS reports the number of people registered in a district broken down by age increments of five years. Using these ABPS data, we estimate the general fertility rate averaged over the last five consecutive years (a-GFR) for the five-year period $i$ in district $j=(1, \ldots, 916)$ as

$$
{\mathrm{a}-\mathrm{GFR}_{i j}}=\frac{(\# \text { children age } 0-4)_{i j}}{(\# \text { women age } 15-49)_{i j}} \times \frac{1,000}{5} .
$$

We take $i=2006-10$ as our main outcome variable. To be precise, a-GFR is a measure of reproduction (fertility and survival), rather than just fertility. In the results section below, we provide additional analysis with infant mortality statistics to separate fertility from the survival chances of children. By using the 2006-10 interval, we ensure that all children born within this time frame are conceived after the 2004 elections. We also calculate a-GFR for 2010-14 (i.e., the most recent period for which fertility data are available). Although a-GFR is not an ideal measure for fertility, we use it because other fertility indicators are not available at the district level (Işik and Pinarcioğlu 2006). In fact, a-GFR is equivalent to the "child-woman ratio" used by Işik and Pinarcioğlu. The only difference is that we divide the child-woman ratio by five, which enables us to interpret a-GFR as an average over five 


\section{A: Districts}

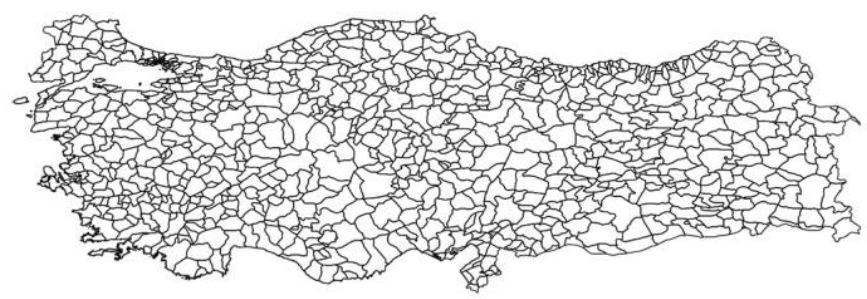

B: AK Parti win/lose margin 2004

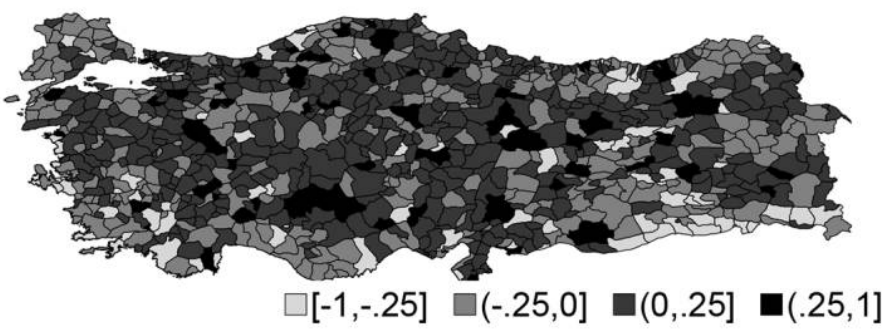

\section{C: General Fertility Rate (2006-2010 average)}

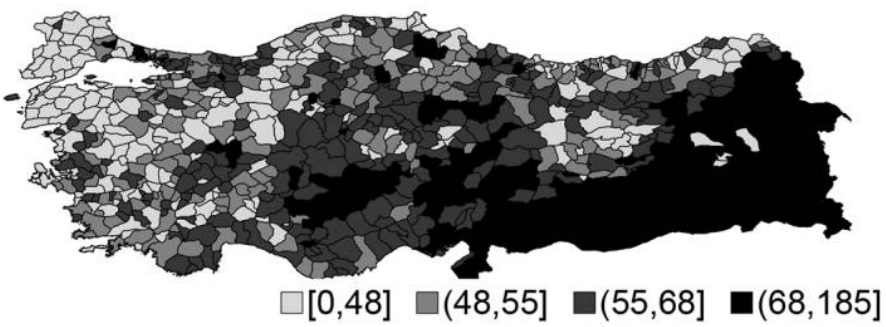

D: Percent Married 2008 (Male 25-44 yrs)

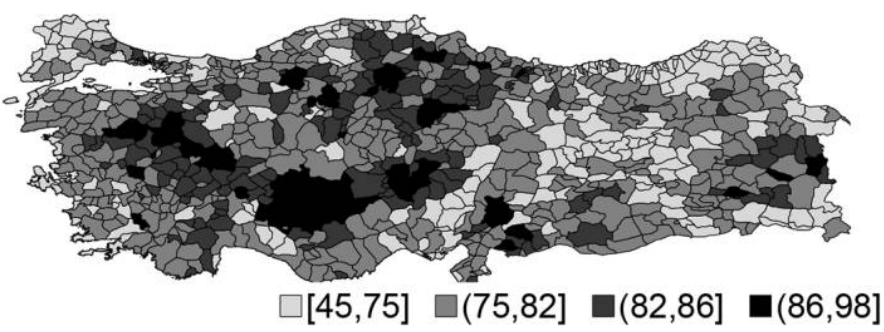

FIG. 2.-Turkey's districts and selected district-level statistics 
consecutive years between 2006 and 2010 and between 2010 and 2014. Figure $2 C$ shows the geographical distribution of a-GFR in 2006-10 across the districts. In line with Işik and Pinarcioğlu (2006), we find a clear geographical variation. Eastern and southeastern districts have very high a-GFR, with a gradual decrease toward the west. The fertility differences shown in figure $2 C$ correspond roughly to an ethnic Turkish versus Kurdish difference in fertility patterns (Koc, Hancioglu, and Cavlin 2008). For a placebo test and as a statistical control, we also calculate a-GFR for 1996-2000 using the 2000 census data.

For what concerns marriage, we use the district-level administrative data that, starting in 2008, TurkStat publishes specifying the number of married and total men and women from 15 years old onward in age increments of five years. We calculate the percentage of married men and women for each five-year age group in 2008 and 2009. The latest marriage data available from TurkStat before 2008 are in the 2000 census. Unfortunately, unlike the data for 2008 onward, the 2000 census does not break down marriage prevalence in five-year increments and includes only the number of married and total men and women who are age 12 and older. Figure $2 D$ shows the distribution of the percentage of married adult men across districts. Note that the percentage of married men and women indicates marriage prevalence rather than incidence. This is perhaps not ideal because some of those who are married in a district by 2008 and 2009 could, in fact, have gotten married before the 2004 elections. We adjust for this problem by taking into account the pre-2004 marriage prevalence by dividing gender- and agespecific marriage prevalence in 2008 and 2009 by gender-specific marriage prevalence in 2000. More formally, we compute the marriage prevalence ratio for each gender $g=(1,2)$, age interval $k=(15-19, \ldots, 40-44)$, year $i=$ (2008, 2009), and district $j=(1, \ldots, 916)$ as

$$
\mathrm{MPR}_{g k i j}=100 \frac{N(\text { married })_{g k i j}}{N_{g k i j}} / \frac{N(\text { married })_{g+2000 j}}{N_{g+2000 j}} .
$$

For what concerns election results, we measure the AK Parti winning/losing margin for each district. Twenty parties and a number of independent candidates participated in the 2004 elections for 916 districts. The AK Parti won $56 \%$ of the districts. We calculate the 2004 AK Parti winning (or losing) margin as the difference between the vote share of the AK Parti and of the largest of the remaining parties in a district. Figure $2 B$ shows the geographical distribution of the district-level AK Parti winning/losing margin. If the winning/losing margin is above zero, the district receives the treatment (i.e., a local AK Parti governance).

As the district-level data set has the highest geographical precision at the relevant electoral unit, we can perform extensive robustness checks and 
analyses, using additional variables. In addition to a-GFR in 1996-2000 and marriage prevalence in 2000, we use the natural logarithm of the number of registered electorate by 2004 as a proxy for district size and the AK Parti vote share in 2004 for specification tests. Additionally, we also compute an indicator of support for political Islam in the pre-AK Parti era, using the vote share of the Virtue Party at 1999 district elections. The Virtue Party was the largest Islamist party in Turkey until $2001 .{ }^{15} \mathrm{We}$ also add to this data set the geographical region and the relative poverty level of the district's province estimated by Doğan (2014).

\section{Province-Level Data Set}

To build our second data set, the province-level data set, we matched election results with administrative data on marriage and fertility (and on some potentially important mediators) at the province level. The district-level data set provides the best geographical precision for the relevant electoral unit and, therefore, provides the best measurement of the key political determinants. However, as we already discussed, fertility and marriage statistics published by TurkStat at the district level are not optimal. At the more aggregate province level, we can make use of better marriage and fertility data (i.e., more precise demographic rates).

For what concerns fertility, from 2009 onward, for each province TurkStat publishes the number of births (rather than the number of children between 0 and 4 years) in a given year. We can thus compute the annual provincial-level general fertility rate (GFR) directly as the ratio between the number of births in a year per 100 women age 16-44. Formally, GFR for province $p=1, \ldots, 81$ and year $j=2009, \ldots, 2014$ is computed as

$$
\mathrm{GFR}_{p j}=\frac{(\# \text { births })_{p j}}{(\# \text { women age 16-49) })_{p j}} 100 .
$$

Unlike a-GFR in equation (1), GFR in equation (3) is not affected by infant mortality.

For what concerns marriage, for each province TurkStat publishes genderspecific annual marriage rates (the number of men and women married in a given year). As our gender-specific provincial measure, we calculate annual marriage rates per 1,000 men and women in a province. For simplicity, we restrict the marriage rates to the combined age range of 16-44 years. Our marriage rate variable covers eight years from 2006 to 2013 . Formally, our provincial marriage rate measure for gender $g=(1,2)$ for the combined 16-44 age cohort in year $i=(2006, \ldots, 2013)$ and province $p=(1, \ldots, 81)$ is

\footnotetext{
${ }^{15}$ We thank an $A J S$ reviewer for pointing us to this potentially important variable.
} 
American Journal of Sociology

$$
\mathrm{MR}_{g i p}=1,000 \frac{N(\text { marriages })_{\text {gip }}}{N_{\text {gip }}} .
$$

For what concerns election results, we have to provide an indirect measure. Each province has a province center, which is also a district. In 2004, for 16 provinces the district center spanned more than one district (metropolitan municipalities). We calculate a province-level AK Parti win/lose margin as the win/lose margin of the AK Parti in the province center or in the metropolitan municipality. Using the win/lose margin at the provincial center is a coarse measure of Islamic governance in a province. This is because while they report to the province center, noncentral districts are separate administrative units. Therefore, measurement error in our province-level analyses will be higher, and this is also the reason why our central results are discussed with reference to the district-level data set. Nevertheless, province centers are the largest and most powerful districts within a province. Hence, the outcomes in the province center likely dominate the provincial demographic and economic indicators. Moreover, any positive result despite the measurement error in our province-level data should be reassuring.

We can use a number of additional province-level variables to test the mechanisms discussed earlier or as controls. We therefore use (1) (natural logarithm of) annual net immigration to a province for the $0-4$ age cohort between 2006 and 2014, (2) (natural logarithm of) annual net immigration to a province for women age 15-49 between 2006 and 2014, (3) annual provincial unemployment rate (in percentage points) between 2008 and 2013, (4) infant mortality per 1,000 births between 2009 and 2014, and (5) genderspecific Quran course participation rate (per 1,000) among the relevant age cohort (between 15 and 49) as an indicator of provincial religiosity. Immigration, unemployment, and infant mortality statistics are published by TurkStat only at the provincial level. The Quran course participation rates are published by the Turkish Presidency of Religious Affairs (TPRA; in Turkish, Diyanet Isleri Baskanligi) at the province level, too. TPRA is a governmental institution established in 1924 whose main aims include "carrying out religious affairs pertaining to faith, worship and moral principles, informing the society on religion and administering places of worship." ${ }^{16}$ The Quran courses organized by TPRA are completely voluntary, take eight months to complete, and treat various topics about the Quran and religion. Obviously the number of people who completed these courses does not cover all aspects of religiosity. Yet, it shows the local demand on training and knowledge about the Quran and Islam and should serve as a good indicator of religiosity.

${ }^{16}$ For further information, see http://diyanet.gov.tr/en-US/Institutional/Detail//1/estab lishment-and-a-brief-history (May 28, 2013; accessed December 21, 2017; in English). 
Individual-Level Data Set

To build our third data set, the individual-level data set, we matched the province-level election measure we just illustrated with the Turkey Demographic and Health Survey conducted in 2013 (TDHS-2013). TDHS-2013 provides a representative sample of Turkish households with a weighted, multistage, stratified cluster sampling approach. All women between age 15 and 49 living in the sampled households were interviewed. This resulted in a sample of 9,746 interviewed women (individual response rate was $90 \%$ and household response rate was 93\%). (For further details of the data set and of the data collection procedure, see Hacettepe University Institute of Population Studies [2014]). This individual-level data set allows us to analyze the effect of local Islamic governance on individual-level marriage and fertility behavior. Moreover, using TDHS-2013 allows us to include a number of potentially important individual-level mediators, such as religiosity, fertility preferences, social security status, and controls such as ethnicity, which are not available in our district- and province-level administrative data sets.

For fertility, using the TDHS-2013 survey, we simply calculate the number of births a woman has given after 2004, that is, after the treatment. For marriage, as TDHS-2013 records the marital status of the respondent, we include only those who were younger than 28 by 2013, which ensures that, because of the legal minimum age of marriage in Turkey (which is 16), in this restricted sample all married women were married after 2004. We then measure whether respondents married after 2004.

For election results, the TDHS-2013 includes the province of the respondent, and all 81 provinces are sampled in the survey. Yet, not all districts are included in the survey. Also, the information about the district of the respondent is suppressed from the publicly available data set. Consequently, we had to match TDHS-2013 with the election outcomes in 2004 at the province level rather than at the district level. We therefore adopted the same strategy as the one illustrated for the province-level data set.

The TDHS-2013 survey provides us with important individual-level information on demographic behavior and other variables that help us in disentangling different mechanisms. Most important, the survey asks about both fertility preferences and differences in constraints women face because of local welfare provision. The survey measures participants' fertility preferences by asking respondents without children "if you could choose exactly the number of children to have in your whole life, how many would that be?" and respondents with children "if you could go back to the time when you did not have any children and could choose exactly the number of children to have in your whole life, how many would that be?" Even if this variable is not a perfect measure of preferences (Johnson-Hanks 2007), it has been used as a standard DHS question to measure the "demand for chil- 
dren" to discuss the impact of population policies (Pritchett 1994). TDHS2013 also measures whether the respondent fasts, veils, and performs the regular namaz. We construct an individual religiosity score as the average of these three items (Cronbach's $\alpha$ is 0.7).

For what concerns welfare, the survey does not include information on whether a respondent or her household received any social assistance from the local government. However, it records whether the respondent has health insurance and if so what kind. About $11 \%$ of all respondents do not have any form of health insurance. Among those who have health insurance, we are particularly interested in whether a respondent has General Health Insurance. Typically, for formally employed women health insurance is provided through the Social Security Institution or private companies. Local authorities do not have a direct influence on those insurances provided by the Social Security Institution or private companies. Additionally, Turkey has a General Health Insurance (GSS) program that aims to cover all individuals who do not have any other social security. GSS, which was formerly called the green card, provides free insurance for those who qualify after an "income test" done by the local municipality. If local Islamic governance affects welfare provision, we should be able to detect this, at least partially, by looking at GSS coverage. We must add that GSS coverage does not entirely capture the extent and effectiveness of all elements of local welfare provision, such as conditional cash transfers, housing aids, prenatal training, and so on. It is, nonetheless, an important element of social welfare. In addition, using TDHS-2013 we further control for age (in years), education (in years), wealth, occupational status, and ethnicity (mother tongue Turkish, Kurdish, Arabic, or other) of the respondent.

Simple descriptive analyses of our data show that there is no significant correlation between the level of support for the AK Parti and fertility, at both the ecological and the individual level. The correlation between the AK Parti rule and the GFR at the province level varies, depending on the year, between -0.03 and 0.02 . At the district level the same correlation is 0.03 in 2010 and -0.01 in 2014. In the individual-level data set the correlation between the AK Parti rule and the number of children a woman had after 2005 is 0.03 . None of those correlations are statistically significant. We will show below that this lack of correlation is, in fact, hiding a real relationship. We now turn to discuss our main analytical strategy, the use of RDD, which has a number of desirable properties in establishing causality.

\section{RDD and the Estimation of Causal Effects}

In order to estimate the effect of AK Parti local rule on marriage and fertility, conventional, regression-based methods that directly compare the treat- 
ment group (districts with the AK Parti winning) with the control group (districts with other parties winning) are not adequate. This lack of adequacy arises because votes for the AK Parti are likely to be correlated with factors (confounders) that, in turn, also influence marriage and fertility, and it is not possible to control for all these confounders. As Gelman and Hill (2006) show, even when accessing all possible confounders, and including them in a regression model, the functional form of the model is crucial in the identification of the causal effect. These difficulties of estimating causal effects are present in almost all conventional regression-based analyses of observational data.

Our identification of causal effects uses the difference between the vote share of the AK Parti and of the largest of the remaining parties as the "running variable" in an RDD. RDD has very good properties to estimate causal effects (see, e.g., Thistlethwaite and Campbell 1960; Hahn, Todd, and Van der Klaauw 2001; Morgan and Winship 2007; Imbens and Lemieux 2008; Lee and Lemieux 2010). It is thus worthwhile to explain the RDD framework in detail. In an RDD a treatment variable $t$ is assigned to observations on the basis of a so-called running variable $x$ and a threshold value $c$. In a typical setting with sharp discontinuity, $t=1$ if $x>c$, and $t=0$ otherwise. In our case, if the difference between the vote shares of the AK Parti and the largest of the remaining parties (the running variable) is larger than zero, then an AK Parti mayor is assigned (treatment); otherwise, a mayor of another party is assigned (control). The generic outcome variable $y$ is predicted using the treatment indicator $t$ and a function of the running variable $x$ for the observation $i$; that is,

$$
E\left(y_{i}\right)=\alpha+f\left(x_{i}\right)+\beta \times t_{i} \quad \text { with } \quad t_{i}=\left\{\begin{array}{l}
1 \text { if } x_{i} \geq c \\
0 \text { if } x_{i}<c
\end{array} \quad \forall x_{i} \in(c-h, c+h)\right.
$$

In equation (5), the $\beta$ coefficient estimates the treatment effect, and $f(x)$ is a control function of $x$ fitted using observations within an $h$ bandwidth around $c$. It is generally advised to fit $f(x)$ separately on both sides of $c$ (i.e., allow the shape of $f(x)$ to vary below and above $c$ within $h$ ), for the relationship between $y$ and $f(x)$ may differ below and above the threshold, and imposing the same function on both sides may introduce bias (de la Cuesta and Imai 2016). The $\beta$ coefficient can be interpreted as a causal effect if the values of the treatment variable $t$ are (as-if) randomly assigned to observations around the threshold value $c$ by nature. In other words, the cases just around the threshold are expected to be balanced on all observed and unobserved confounders, just as in a randomized experiment, therefore creating a natural experiment. This design allows us to interpret $\beta$ as the es- 
timate of a causal effect. ${ }^{17}$ RDDs are widely used in political science, and in close popular elections based on a majoritarian system, the (as-if) randomness assumption is shown to hold in almost all cases (Eggers et al. 2015). This is because in popular elections random noise in the electoral system, such as a few pro- or anti-AK Parti voters failing to turn up because of illness or accident, is sufficient to tilt the results of very close elections in one way or the other.

One can test whether the assumption of randomness around the threshold. One way of testing is to compare cases just around the threshold with respect to the values of pretreatment covariates using the same RDD model in equation (1) but replacing $y$ with pretreatment covariates. If the assignment is indeed (as-if) random, one should not find any significant differences between the treatment and control in pretreatment covariates. A second test is the so-called McCrary's (2008) density test. This test does not require any pretreatment covariates because it compares simply the density of the running variable $x$ around the threshold. If the as-if randomness assumption holds, one should not see any discontinuity in the density. If, however, there is sorting (which means that certain types of cases are more successful in crossing over the threshold), this will create imbalances in the density of $x$ around the threshold. Such imbalances are detected by McCrary's test. We present below the results of these tests in our case. Such tests should be performed routinely for any application of an RDD.

As recommended in de la Cuesta and Imai's (2016) review of the RDDs in close elections, we use a local linear specification for $f(x)$, fitted separately below and above $c$ (Nichols 2007, 2014), and the standard Imbens and Kalyanaraman (2012) method to estimate an optimal bandwidth $\hat{h}$ for a given outcome variable. ${ }^{18}$ There are two other, rather small, Islamic parties, namely, Saadet Partisi (Felicity Party) and BBP (Great Union Party), that also participated in the elections. As in Meyersson (2014), one could calculate Islamic win/lose margin as the difference between the vote share of the largest Islamic party (i.e., the largest of the AK Parti, the Saadet, and the BBP) and of the largest secular party (i.e., the largest among the rest). In our case, this alterna-

\footnotetext{
${ }^{17}$ Technically, $\beta$ can be interpreted as an estimate of a causal effect if the potential outcomes are continuous at $c$ (de la Cuesta and Imai 2016). This is a less stringent assumption than as-if randomness around $c$. This nuance is not important in application as long as $f(x)$ is appropriately included in the analysis.

${ }^{18}$ Our appendix, available online, includes extensive robustness checks with alternative bandwidths and specifications of $f(x)$. It also includes robustness checks of our measures of fertility, marriage, and province-level RD results, as well as of the effects of AK Parti governance on marriage prevalence rather than marriage prevalence ratios at the district level. Finally the appendix includes descriptive statistics for the variables we use in our district-level, province-level, and individual-level data sets and some bivariate correlations.
} 
tive operationalization makes no difference. In 2004 neither the Saadet nor the $\mathrm{BBP}$ won any of the 81 province centers, and the BBP won only three of the 916 districts. Consequently, the results we present are virtually identical to the results obtained with this alternative operationalization. As the AK Parti win/lose margin can also be interpreted as the Islamic win/lose margin, in what follows we use local AK Parti governance and Islamic governance interchangeably.

An important point about RDDs is that while they enable estimation of causal effects, this estimated effect is local. This is because the analysis is restricted to the cases within an $h$ bandwidth around the threshold. ${ }^{19}$ This may hinder external validity, that is, drawing inferences about the causal effect for cases away from the threshold. In our case, for example, what we can estimate with an RDD is the causal effect of Islamic governance in highly contested areas. Depending on the particular application and whether the cases around the threshold are expected to be different from the cases far away from the threshold, this external validity issue may or may not be a problem. We will discuss this point after presenting our results and argue that external validity issues are less problematic in our case.

RDDs based on close electoral races have been applied in political science to study electoral effects (Caughey and Sekhon 2011; Eggers et al. 2015). Similarly, RDDs have been used to great acclaim in economics and educational research (Morgan and Winship 2007; Gangl 2010) but have remained mostly unexploited so far in sociology (Bernardi 2014).

\section{Tests of the RDD Identification Assumption}

Before presenting our main results, we discuss a number of validity tests (Imbens and Lemieux 2008; McCrary 2008; Lee and Lemieux 2010) for the RDD. The results of these tests are depicted in figure 3. First, we perform a McCrary (2008) test of discontinuity of the density at the threshold (upper-left panel). The test returns a discontinuity estimate of 0.14 with a standard error of 0.17 , showing no significant jump at the threshold. ${ }^{20}$ Moreover, the figure shows that the majority of the districts are located close to the threshold, so that analyses based on the discontinuity at the threshold are relevant for an important number of districts in Turkey. In fact, the number of districts around the threshold that are used to calculate our subsequent RD estimates turns out to be more than half of all districts. This indicates that while by definition

${ }^{19}$ While there are methods proposed to extrapolate RDD results to the cases away from the threshold, the usefulness of those methods has been questioned, as they imperil the design's main advantage in internal validity (de la Cuesta and Imai 2016).

${ }^{20}$ On a minority of occasions, outcomes of close elections are shown to be nonrandom (Caughey and Sekhon 2011; but also see Eggers et al. 2015). We do not find evidence against randomness of close elections in 2004 for district-level outcomes. 
American Journal of Sociology
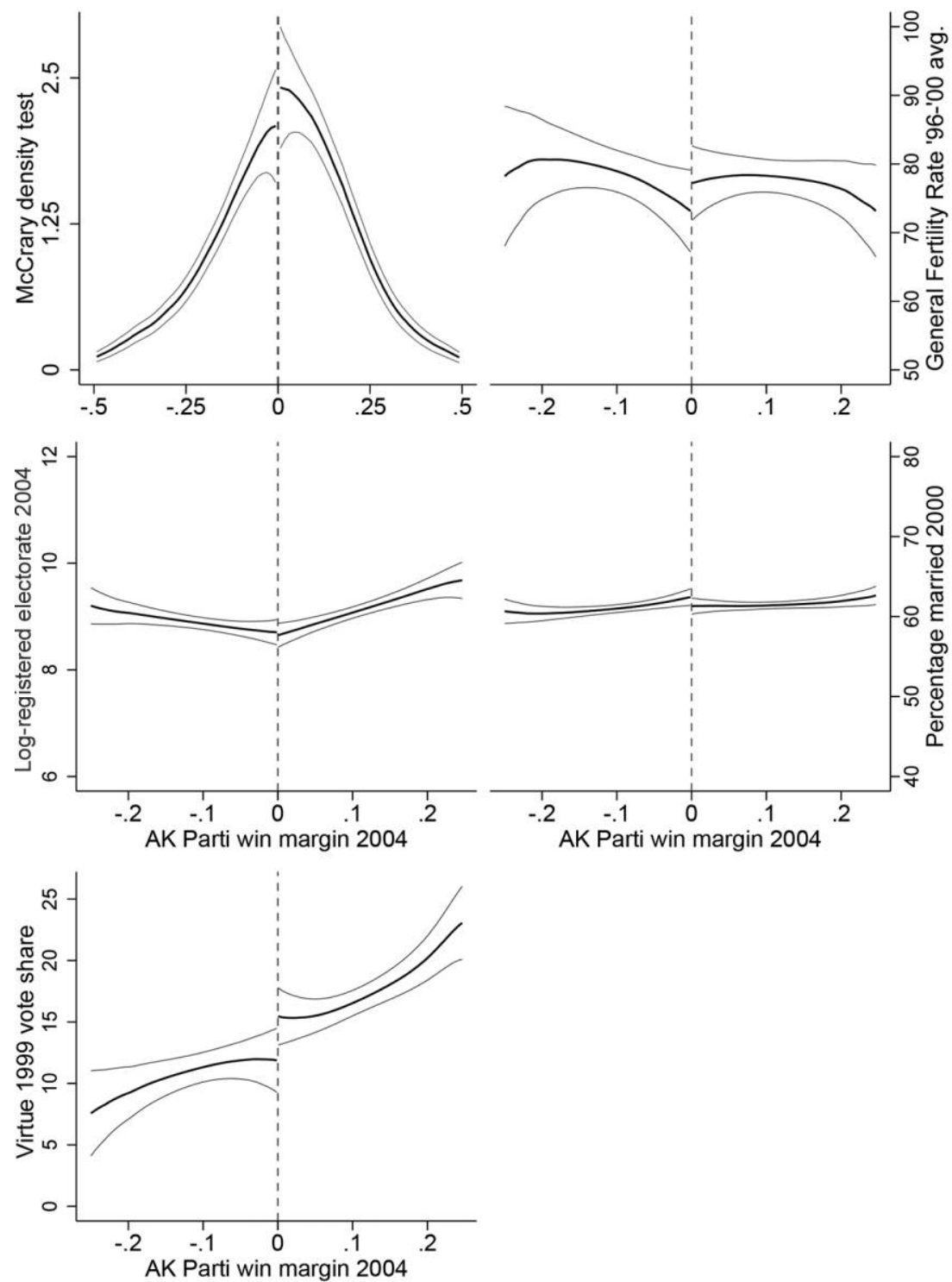

FIG. 3.-Validity checks and placebo tests

an RD estimate is local, in our case the estimated local effect is also externally valid as it is based on the majority of cases.

Second, we inspect whether a number of pretreatment variables display discontinuities at the threshold, as "placebo tests." Such discontinuities of control variables, if they existed, would undermine the identification as- 
sumptions of the RDD. There is no significant discontinuity when the number of registered electorate in 2004 is considered. Most important, there is no significant RD effect of the 2004 elections on a-GFR in 1996-2000 and on marriage prevalence in 2000, four years before the elections. Finally, there is no significant RD effect of the 2004 elections on the support for political Islam in the pre-AK Parti era, measured by the vote share of the Virtue Party in 1999. Consequently, we conclude that an RDD is valid in our case, and we have a natural experiment in which incumbency is assigned as-if randomly across districts at the winning threshold.

\section{MAIN RESULTS}

Fertility

Applying RDD to our district-level data set, we find that local Islamic governance in 2004 has yielded on average about 7.75 more annual children per 1,000 women between 2006 and 2010 (Imbens and Kalyanaraman [KI] optimal bandwidth $=.15 ; N=541$ ). This effect is statistically significant. Figure 4 presents the RDD estimation, including point estimates and standard errors, which are robust to nonnormality and clustering of districts within provinces. ${ }^{21}$

When we control in the same RDD model for fertility in 1996-2000, number of registered electorate in 2004 (logged), geographical region (dummies for east and southeast Anatolia), percentages of married men and women in 2000, the relative poverty of the district's province, and support for political Islam in 1999, the effect is reduced to 5.24 but remains statistically significant (cluster robust $\mathrm{SE}=2.476$, two-sided $P<.05$ ). While the effect size decreases after adding these controls, the difference with and without controls is, in fact, statistically insignificant $\left(\chi^{2}(1)=1.06\right.$, two-sided $\left.P=.32\right)$ - this result is obtained using the seemingly unrelated estimation approach of Weesie (1999).

\footnotetext{
${ }^{21}$ The number of districts is slightly larger in 2006-10 and 2010-14 than in 2004. When we estimate the RD effects, we exclude the new districts that split from the districts that already existed in 2004. To check whether this exclusion may have affected our results, we reestimated the $\mathrm{RD}$ effect but this time including only the districts belonging to provinces in which there was no change in the number of districts after 2004. In this alternative estimation, there cannot be any selection effect, as the number of districts has been stable throughout. The RD effect obtained for this subset is in fact larger and significantly different from zero but not significantly different from that reported in fig. 4 (difference $=$ $4.13, \mathrm{SE}$ of difference $=5.55, P$-value for test of difference $=0.46$ ). Moreover, in our province- and individual-level analyses below, we use all cases (as the independent variable is at the province level and the number of provinces has been constant) and obtain qualitatively the same results. Hence, we conclude that our results are robust with respect to the missing observations at the district level.
} 

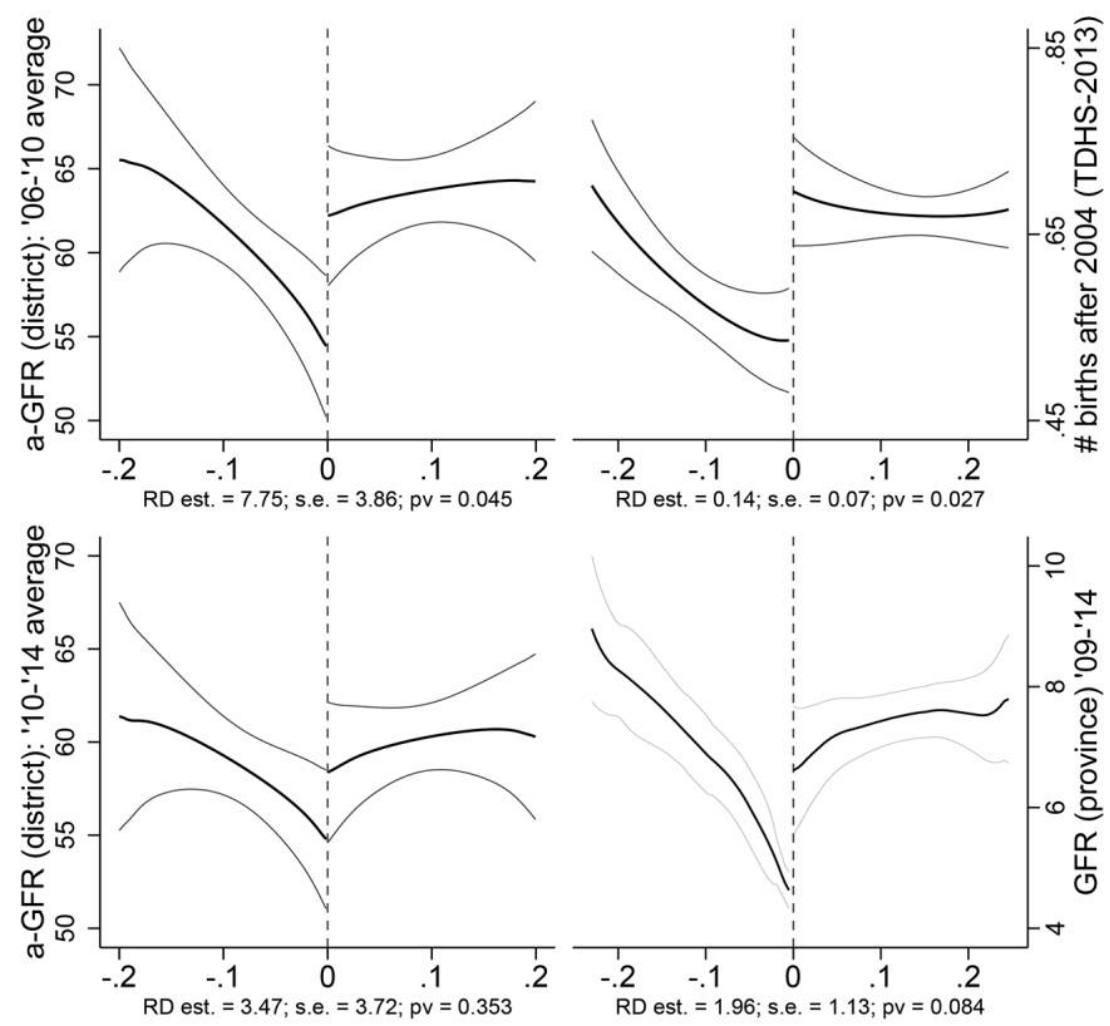

AK Parti win margin 2004

FIG. 4.-Local Islamic governance and fertility. Left top and bottom, district-level outcomes by district-level election results; right top, individual-level outcomes by provincelevel election results; right bottom, province-level outcomes by province-level election results. Includes local polynomial smoothers (thick lines) with gray lines as $90 \%$ confidence intervals. Local linear RD point estimates for KI optimal bandwidths, their cluster-adjusted robust SEs, and two-sided $P$-values are included below each panel.

The lower-left panel in figure 4 shows that there has been a positive, yet not statistically significant, effect also for 2010-14 (KI optimal bandwidth $=.125$; $N=467$ ). While this estimate shows that the effect of local Islamic governance in 2004 does not seem to influence demographic behavior in 2010-14 to the same extent as it does in 2006-10, it also implies that the increase in fertility in 2006-10 is not counterbalanced by a successive decrease. A smaller effect is to be expected as the leading party has shifted in some districts. This lack of a negative effect on the 2010-14 outcomes also denotes the absence of what in demography is known as a pure tempo effect (i.e., an effect due to the average age at birth and not to total fertility; Bongaarts and Feeney 1998). 
Applying the RDD approach to our province-level data set, we find that local Islamic governance in 2004 in the province center has yielded, on average, about 1.96 more births in a province per 100 women between age 16 and 49 (KI optimal bandwidth $=0.16 ; N=240$; see fig. 4 bottom-right panel for the cluster robust standard error and the $P$-value). Because the provincial-level measure of fertility is annual (rather than a five-year average as at the district level), we can test whether this causal effect diminishes over time. We provide the result of this test in the next section in which we further discuss the mechanisms.

Applying RDD to our individual-level data set, we find that local Islamic governance in the province center increases the number of births after 2005 by 0.14 (KI optimal bandwidth $=0.18 ; N=5,377$; see top-right panel in fig. 4). This estimate remains effectively unchanged when we control for a number of important individual covariates, that is, age, number of births before 2005, education, wealth, individual religiosity, ideal number of children, whether the respondent has General Health Insurance, occupational status, and ethnicity, and province random effects ( $\mathrm{RD}$ coefficient after controls $=$ $0.14, \mathrm{SE}=.07, P=.047)$.

Two features of those findings are important for the external validity of our results. First, recall that because of the distribution of the running variable, the majority of districts are within the $c$ bandwidth around the threshold. This is because, in most districts, the race between the AK Parti and the largest remaining party has been highly contested. Hence, while an RDD estimate is, by its nature, valid for highly contested districts, because in 2004 most districts are highly contested, our results apply directly to the majority of cases. Second, note in figure 1 the association between fertility and the AK Parti win/lose margin below and above the winning threshold of zero. Fertility decreases steadily as the AK Parti win/lose margin increases, but only until the threshold. At the threshold fertility jumps, which is the base of our RDD estimates. Above the threshold, however, fertility remains relatively stable or increases slightly as the AK Parti win/lose margin further increases. These trends are similar for the district-, province-, and individuallevel analyses. If we were to extrapolate the causal RDD estimate obtained at the threshold to the cases away from the threshold, particularly to the districts in which the AK Parti has a large margin of victory, we would need to extrapolate the trend to the left of the threshold to the right. This extrapolation would show what would have happened in those districts with a large AK Parti win margin had those districts been ruled by a non-Islamist party (i.e., the potential outcomes above the threshold), assuming that the trend to the left of the threshold would also apply throughout. Then, we could compare the extrapolated line with the actual trend estimated above the threshold. This exercise would clearly show that the effect estimated at the threshold would not be smaller in districts with a large AK Parti win margin; in 




FIG. 5.-Local Islamic governance and age-specific marriage prevalence ratios among men $(A)$ and women $(B)$ at the district level. Includes local polynomial smoothers (thick lines) with gray lines as $90 \%$ confidence intervals. 

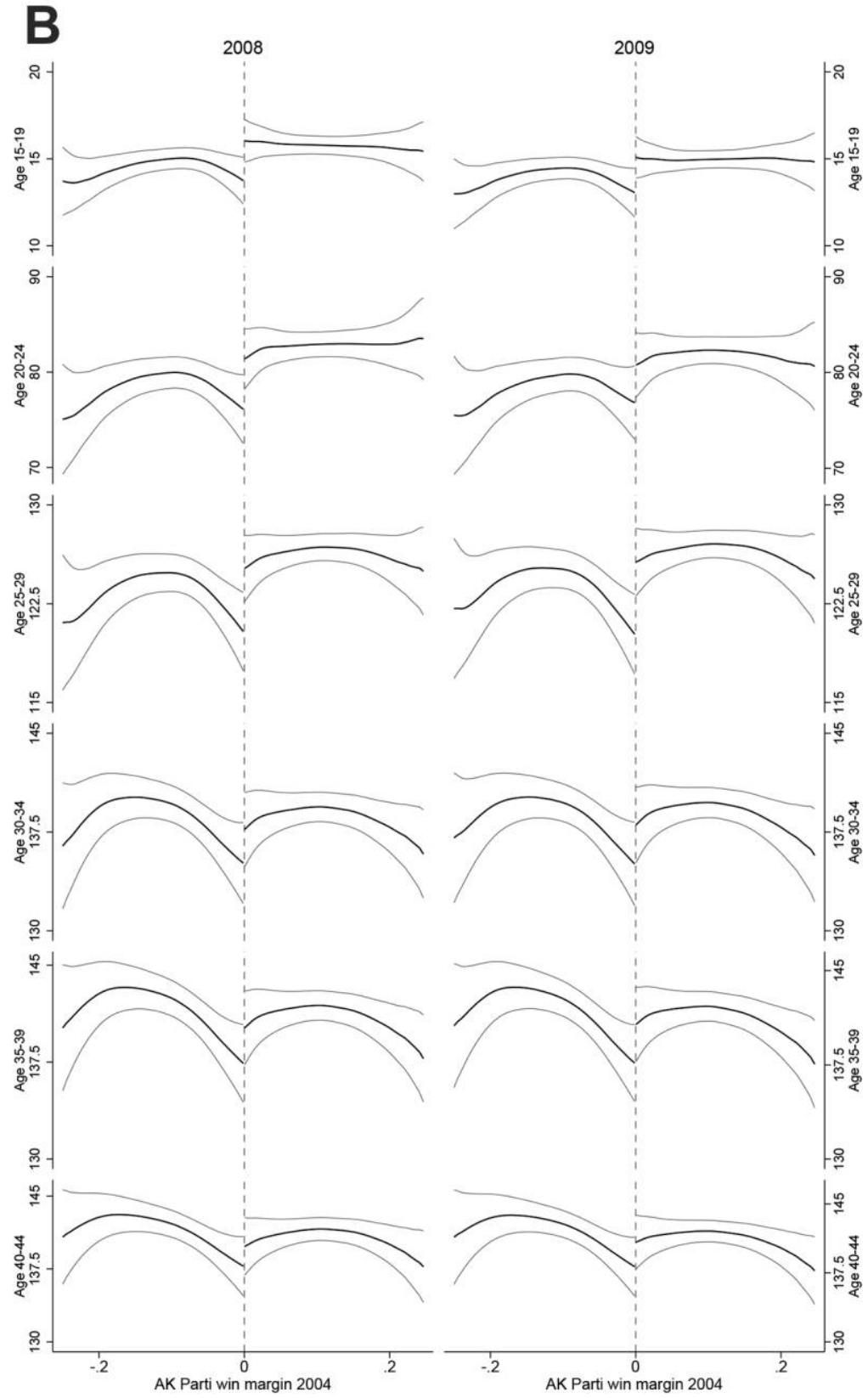

FIG. 5.-(Continued $)$

\section{3}

This content downloaded from 128.041.061.032 on May 23, 2018 10:19:10 AM

All use subject to University of Chicago Press Terms and Conditions (http://www.journals.uchicago.edu/t-and-c). 
fact, the effect size would be higher. ${ }^{22}$ If the AK Parti had concentrated only in highly contested areas (i.e., potential "swing districts") and not invested in districts in which they won comfortably, we would see a decreasing trend to the right of the threshold, too, which is obviously not the case. Hence, our results not only apply to highly contested districts, but they seem to apply also to cases away from the threshold.

\section{Marriage}

For the district-level data set, figure 5 presents the RDD results for marriage prevalence ratios. Table 1 includes local linear $\mathrm{RD}$ point estimates for optimal bandwidths and their robust standard errors. These estimates show that local Islamic governance has had a significant positive effect on marriage prevalence among adult men in 2008 and 2009 relative to marriage prevalence in 2000. The effect for men is quite consistent for 2008 and 2009 as well as for separate age groups, although it is strongest within the 25-44 years range (see fig. 5A).

AK Parti rule also has a positive and significant effect on female marriage prevalence ratios, especially among the younger age groups (15-34 years). For older age groups, standard errors are relatively high. It seems that female marriage ratios, particularly among older cohorts, are generally less responsive to local political rule than male marriage ratios (see fig. $5 \mathrm{~B}$ ).

Using the province-level data set, the RDD estimate of the effect of local Islamic governance in 2004 on female marriage rates is obtained as 4.41 (KI optimal bandwidth $=0.22 ; N=440$ ) and on male marriage rates as 3.82 (KI optimal bandwidth $=0.32 ; N=544$ ). Both effects are statistically and substantially significant (see fig. 6 for those effects with cluster robust standard errors and $P$-values). Below we test whether these effects vary over time.

Using the individual-level data set, we obtain an RDD estimate of the effect of local Islamic governance in the province center on the probability of being married, provided that a respondent is younger than 28 by 2013 (i.e., the marriage has happened after the 2004 elections). Figure 6 (bottom panel) shows that Islamic governance increases the probability of being married by about 10 percentage points (KI optimal bandwidth $=0.27 ; N=2,806$ ). This effect is both statistically and substantially significant. This estimate remains effectively unchanged when we control for age, education, wealth, ideal number of children, occupational status, ethnicity, and province random effects (RD coefficient after controls $=0.10, \mathrm{SE}=.053, P=.059)$.

\footnotetext{
${ }^{22}$ This extrapolation exercise should be treated with caution, as it relies on untestable assumptions due to the "fundamental problem of causal inference," such as that the trend to the left of the threshold would apply to the right of the threshold, too (see de la Cuesta and Imai 2016).
} 
TABLE 1

Local Linear Regression Discontinuity Estimates of the EfFect of AK Parti Rule in 2004 on Marriage Rates

\begin{tabular}{|c|c|c|c|c|c|c|c|c|}
\hline & $15-19$ & $20-24$ & $25-29$ & $30-34$ & $35-39$ & $40-44$ & $25-44$ & $15-44$ \\
\hline \multicolumn{9}{|l|}{ Men: } \\
\hline \multirow[t]{3}{*}{2008} & $.28^{+}$ & 2.21 & $10.88 * *$ & $10.62 * *$ & $7.95 *$ & $5.69^{+}$ & $8.70 * *$ & $3.69^{+}$ \\
\hline & $(.16)$ & $(1.66)$ & $(3.93)$ & $(3.62)$ & $(3.39)$ & $(3.23)$ & $(3.14)$ & $(2.16)$ \\
\hline & [.22] & {$[.13]$} & [.09] & [.09] & {$[.10]$} & [.11] & [.09] & [.07] \\
\hline \multirow[t]{4}{*}{2009} & .13 & 2.17 & $12.01 * *$ & $9.30 * *$ & $8.35 *$ & $6.35^{+}$ & $8.95 * *$ & $3.43^{+}$ \\
\hline & $(.15)$ & 1.69 & $(4.04)$ & $(3.54)$ & $(3.36)$ & $(3.39)$ & $(3.27)$ & (1.99) \\
\hline & [.19] & {$[.14]$} & [.09] & [.10] & {$[.10]$} & [.11] & [.08] & [.09] \\
\hline & & & & & & & $15-34$ & $15-44$ \\
\hline \multicolumn{9}{|l|}{ Women: } \\
\hline \multirow[t]{3}{*}{2008} & $2.87 *$ & $6.13 *$ & $5.17 *$ & 3.21 & $3.44^{+}$ & 2.72 & $3.81 *$ & $2.76^{+}$ \\
\hline & $(1.42)$ & $(3.01)$ & $(2.31)$ & $(2.21)$ & $(2.04)$ & $(1.96)$ & $(1.59)$ & $(1.59)$ \\
\hline & {$[.11]$} & [.17] & [.14] & [.15] & {$[.15]$} & [.17] & [.13] & [.13] \\
\hline \multirow[t]{3}{*}{2009} & $2.42^{+}$ & 2.79 & $5.87 *$ & 3.50 & 3.17 & $3.31^{+}$ & $3.56^{*}$ & 2.03 \\
\hline & $(1.35)$ & $(2.15)$ & $(2.30)$ & $(2.28)$ & $(2.25)$ & $(2.00)$ & $(1.79)$ & $(1.76)$ \\
\hline & {$[.12]$} & {$[.38]$} & [.14] & [.15] & {$[.11]$} & [.17] & {$[.11]$} & [.12] \\
\hline
\end{tabular}

NotE.-Marriage rates are age and gender specific and divided by total gender-specific marriage rates in 2000. The optimal bandwidths are estimated with the Imbens and Kalyanaraman (2012) method. Cluster- and nonnormality-adjusted robust SEs are in parentheses; optimal bandwidths are in square brackets.

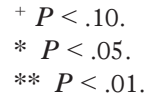

\section{Heterogeneous Effects and Health Insurance}

We hypothesized that the mechanisms that yield the previous substantial causal effects are related to the wave of socioeconomic assistance the AK Parti has launched through local authorities who targeted young families, mothers, and in general the poor. We use two strategies to assess this hypothesis. First, we test whether the causal effect of local Islamic governance is heterogeneous and stronger in poorer areas. This is because, first, social assistance is expected to be more prevalent in poorer districts, and, second, it will have a larger marginal effect (thus will be more efficient) for the poor. Second, we test whether the AK Parti rule has a significant causal effect on General Health Insurance coverage (as opposed to no coverage).

Using the province-level data set, we estimate conditional (heterogeneous) causal effects through an interaction of the binary treatment indicator (AK Parti governance) with the poverty ranking of the district's province using the same RDD reported above. The poverty rankings of provinces are calculated by Doğan (2014) using a number of poverty indicators published by TurkStat. As we have an appropriate causal design, we can estimate 

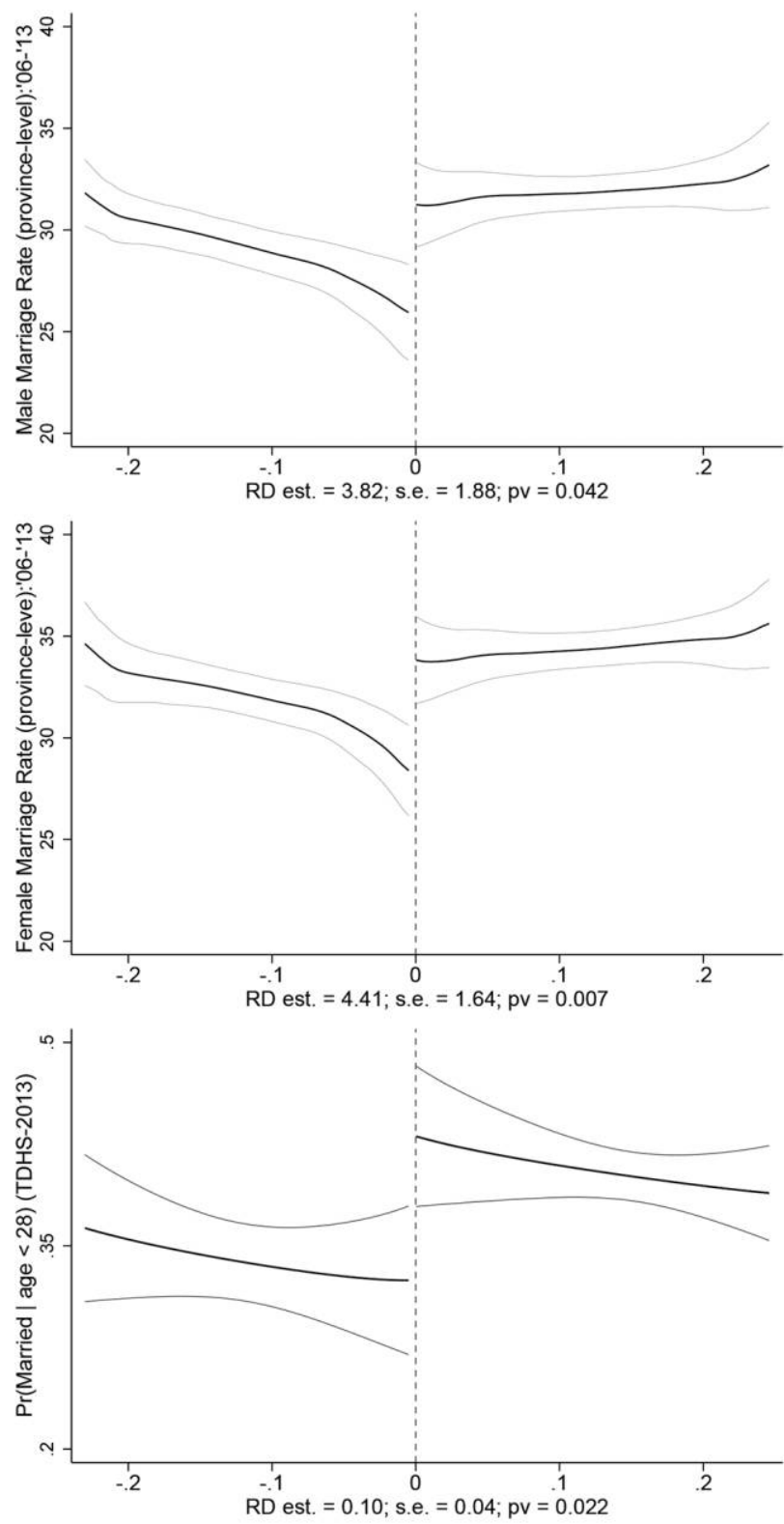

AK Parti province center win margin 2004

FIG. 6.-Local Islamic governance in the province center and annual marriage incidence rate at the province level (top and middle) and the probability of being married at the individual level (bottom). Includes local polynomial smoothers (thick lines) with gray lines as $90 \%$ confidence intervals. Local linear RD point estimates for KI optimal bandwidths, their robust SEs, and two-sided $P$-values are included below each panel. 
heterogeneous causal effects free from sample selection bias (Breen, Choi, and Holm 2015). We find that indeed the causal effects of Islamic governance on fertility are heterogeneous. The top two panels of figure 7 show these effects by poverty ranking: effects on fertility in 2006-10 and in 2010-14 are the strongest and statistically significant in poorer areas, but they are not statistically significantly different from zero in the richest areas. However, we do not find any evidence that the causal effects of Islamic governance on male and female marriage prevalence ratios are heterogeneous (results available on request).

Using our individual-level data set and our RDD strategy, we find a very strong and statistically significant welfare effect (see the bottom panel of fig. 7): Islamic governance increases the probability of having General Health Insurance coverage, as opposed to having no coverage, by about $0.27 \%$ (KI optimal bandwidth $=0.19 ; N=1,240$ ). This effect of Islamic governance on insurance coverage is very similar among both employed $(\mathrm{RD}$ estimate $=$ 0.21 , cluster robust $\mathrm{SE}=0.09, P=.022 ; \mathrm{KI}$ optimal bandwidth $=0.19$ : $N=605)$ and unemployed $(\mathrm{RD}$ estimate $=0.31$, cluster robust $\mathrm{SE}=$ $0.13, P=.019$; KI optimal bandwidth $=0.37 ; N=999)$ women. In turn, having General Health Insurance has a positive effect on the number of children born after 2005, even after controlling for the AK Parti rule, the running variable (winning/losing margin), age, number of births before 2005, education, wealth, religiosity, ideal number of children, occupational status, and ethnicity (coefficient $=.075, \mathrm{SE}=.039, P=.053$ ).

\section{TESTING ALTERNATIVE OR COMPLEMENTARY MECHANISMS}

We have documented a causal effect of local Islamic governance on subsequent marriage and fertility behavior using data from different levels and sources. We have interpreted this finding in light of our hypothesis that this result depends on the local charity-based social assistance system promoted by the AK Parti and provided evidence in support of this mechanism. In our hypotheses and mechanisms section, we anticipated a number of alternative or complementary mechanisms that would explain the causal effect of AK Parti governance on fertility and marriage through pathways different from local welfare provision. In this section we provide additional evidence using the province-level and individual-level data set.

A first alternative is the economic development mechanism: districts ruled by the AK Parti mayors might have thrived from an economic point of view, and this would imply higher fertility and marriage rates. This economic effect would be a plausible consequence of the support of the central AK Parti government. Here, our key test uses province-level data from TurkStat on the most relevant indicator of the economic cycle, namely, annual unemployment rates between 2008 and 2013. 

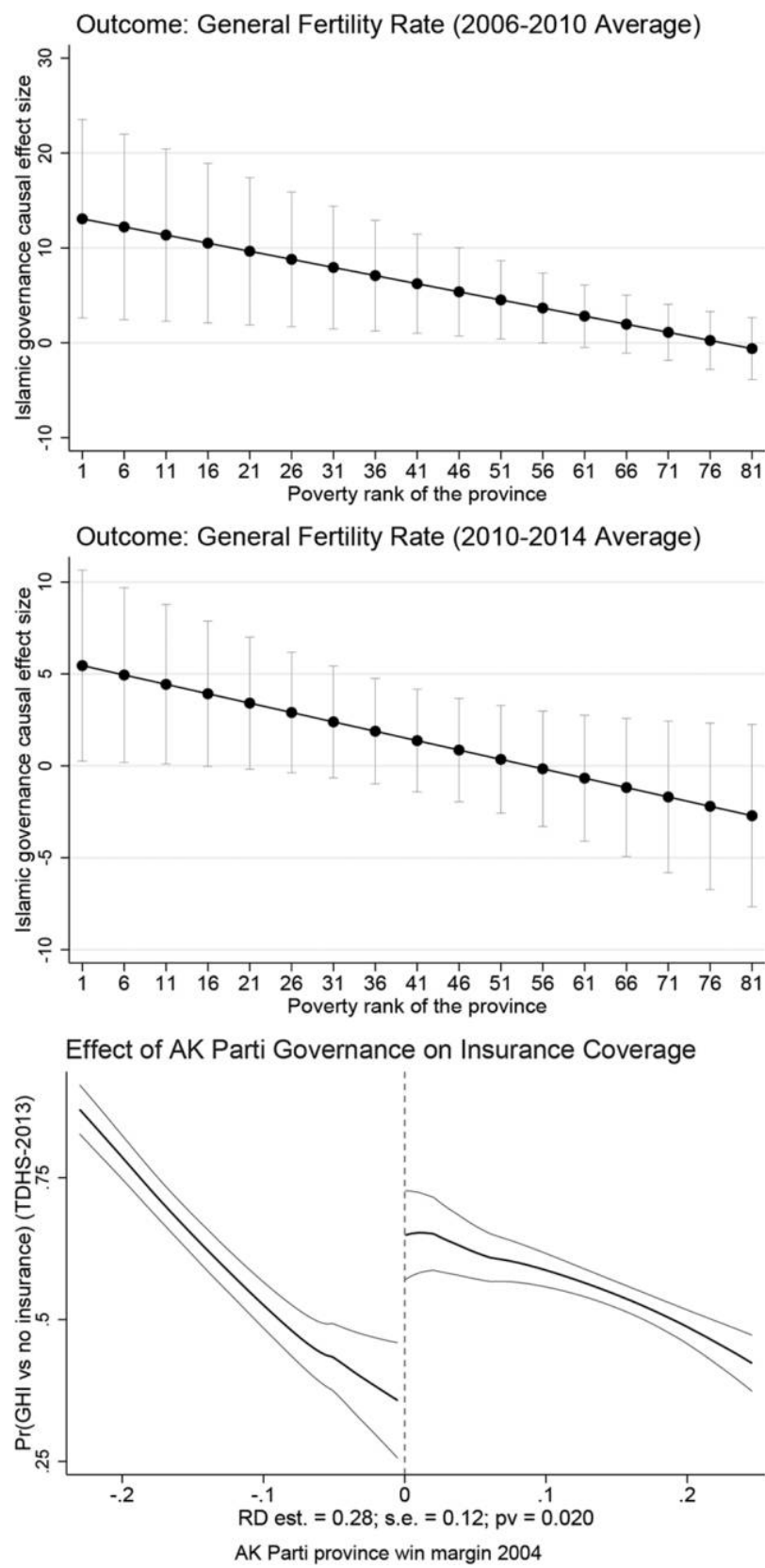

FIG. 7.-Top and middle, heterogeneous causal effects of district-level Islamic governance by the poverty ranking of district's province; $90 \%$ confidence intervals are included. Bottom, causal effect of Islamic governance in the province center on the probability of having General Health Insurance as opposed to no insurance; gray lines as 90\% confidence intervals, local linear RD point estimate for KI optimal bandwidth, its robust SE, and the two-sided $P$-values are included below the panel. 
A second alternative is the religiosity mechanism: residents of the districts ruled by the AK Parti could have become more religious because of the Islamic stance of the ruling party. This increase in religiosity per se could have changed preferences and resulted in more marriages and higher fertility, even if there is no prior evidence that clearly shows that a higher religiosity per se results in a higher propensity to marry and higher fertility (McQuillan 2004). In this subsection, we address potential effects of the AK Parti rule on religiosity, first, using the TPRA data on Quran course completion rates and, second, using the TDHS-2013 data on individual-level religiosity.

Third, there is the preference mechanism: local AK Parti governance may have effected fertility not through affecting constraints but through changing fertility preferences of families because of, for example, AK Parti's pure pro-natalist or conservative rhetoric. This mechanism is similar to the religiosity mechanism discussed above. Using our individual-level data set, we can test directly whether local AK Parti governance effects the ideal number of children, which is a fine measure of fertility preferences.

Fourth, there is the infant health mechanism. In this case, the increase in the share of surviving children up to age 5 (an indicator of net reproduction) would be explained by a decrease in infant mortality, rather than by an increase in fertility rates (an indicator of gross reproduction). This is a complementary type of pathway as it still relies on local welfare provision. We must add, however, that the effect of the AK Parti rule on marriage rates suggests that the effect of the AK Parti on fertility cannot be only due to differential infant mortality. To address infant health, we analyzed the annual number of infant deaths before reaching age 1 per 1,000 births, from 2009 to 2014, at the provincial level.

Finally, there is the welfare migration mechanism: districts ruled by the AK Parti may have attracted more married couples and families with children or with a higher propensity to marry or have children. This pathway is also a complementary one, because it relies on migration as related to local welfare provision. We computed two relevant indicators: immigrants and emigrants among 0-4-year-old children and immigrants and emigrants among 15-49-year-old women. We then computed an indicator relating immigrants and emigrants and used a logarithmic transformation.

Figure 8 shows the relationship between Islamic governance in a province center and the provincial-level economic, religious, immigration, and infant mortality outcomes. The figure shows that local Islamic governance has no significant causal effect on subsequent unemployment rates. Thus, the first necessary condition of an explanation of the causal effect of Islamic rule through an economic pathway is rejected. Local Islamic governance does seem to have an effect on Quran course completion rates, however, but only among women (for women, $\mathrm{RD}$ estimate $=10.89$, cluster robust $\mathrm{SE}=6.44$, two-sided $P=.09$ for the optimal bandwidth of .13 , with 

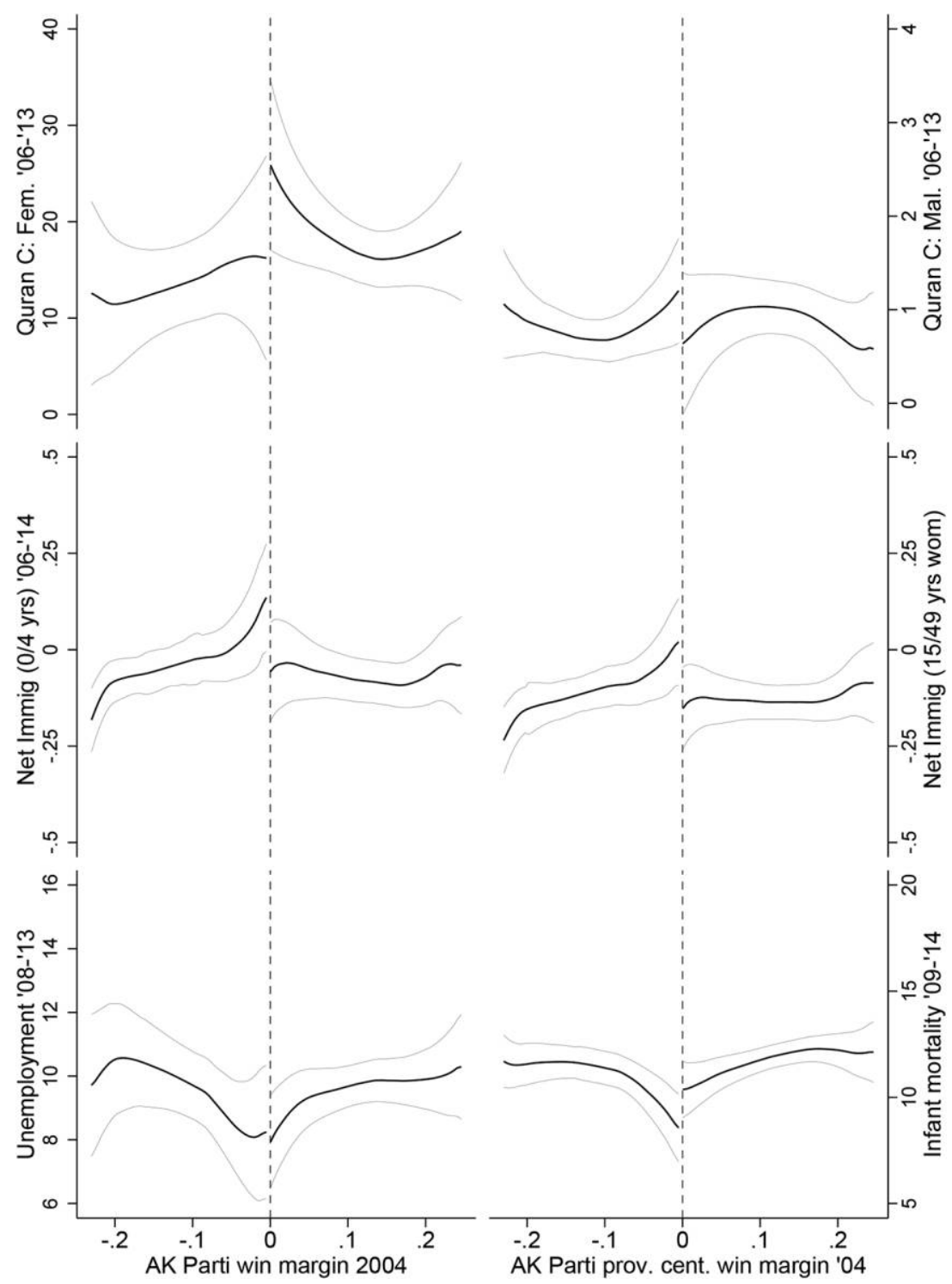

FIG. 8.-Causal effect of Islamic governance in the province center on potential provincelevel mediators: unemployment rate, the proportion of women and men (among 16-49year-olds) who completed the Quran Course of the Turkish Presidency of Religious Affairs (per 1,000), net (logged) immigration of 0-4-year-old children and 15-49-year-old women, and infant mortality (per 1,000 births). Includes local polynomial smoothers (thick lines) with gray lines as confidence intervals. 
$N=180$; for men, $\mathrm{RD}$ estimate $=-.69, \mathrm{SE}=.80$, two-sided $P=.39$ ). Islamic governance in the province center does not have a significant causal effect on net child immigration $(\mathrm{RD}$ estimate $=-0.263$, cluster robust $\mathrm{SE}=$ 1.70 , two-sided $P=-.122$ for the optimal bandwidth of .11), on net immigration among fertile women $(\mathrm{RD}$ estimate $=-0.123$, cluster robust $\mathrm{SE}=$ 1.11 , two-sided $P=.244$ for the optimal bandwidth of .18), and on infant mortality $(\mathrm{RD}$ estimate $=1.488$, cluster robust $\mathrm{SE}=0.988$, two-sided $P=$ .132 for the optimal bandwidth of .20). In fact, although insignificant, the effects of Islamic governance on net child immigration and infant mortality are negative and positive, respectively. The directions of these insignificant effects are against the alternative explanations of the positive effects of Islamic governance on marriage and fertility we document in this article.

Figure 9 shows, using our individual-level data set, the relationship between local Islamic governance and individual measures of religiosity and the ideal number of children. As apparent from the figure, we do not find any significant RD effect on the ideal number of children or on the individual measure of religiosity.

As discussed above, although Islamic governance does not have an effect on individual religiosity, it seems to have an effect on Quran course completion rates at the province level. We now consider the other necessary conditions for the two alternative pathways, namely, the path from unemployment and Quran course completion to marriage and fertility. For this purpose, we fit a series of multilevel regression models with random effects at the province level, to predict GFR and marriage rates from 2009 to 2014. Table 2 presents the results of these models. Each model includes dummy variables for years, with 2009 as the reference category. We also include a random slope for the linear time trend $(t=$ year -2009$)$ per model. Each model in table 2 is a "compound symmetry model," with a random slope for time, which is a typical model for longitudinal data (Snijders and Bosker 2012, chap. 15). We do not regress fertility and marriage on net immigration and infant mortality because these latter two measures are, by construction, related to the two dependent variables.

The models in table 2 also include dichotomous controls for east and southeast Anatolia and logged and centered province population as control variables. Models M3, M6, and M9 include a dummy variable that indicates whether the province center was won by the AK Parti in 2004. The models also include one-year lagged measures of the unemployment rate and the proportion of men and women who completed the TPRA Quran courses. The lagged measures rather than the current measures are included because the current measures of these time-varying independent variables would be highly endogenous to the outcome variables.

All models indicate a decreasing trend in fertility and marriage over time. However, this trend is experienced differently in different provinces; that is, 


\section{American Journal of Sociology}
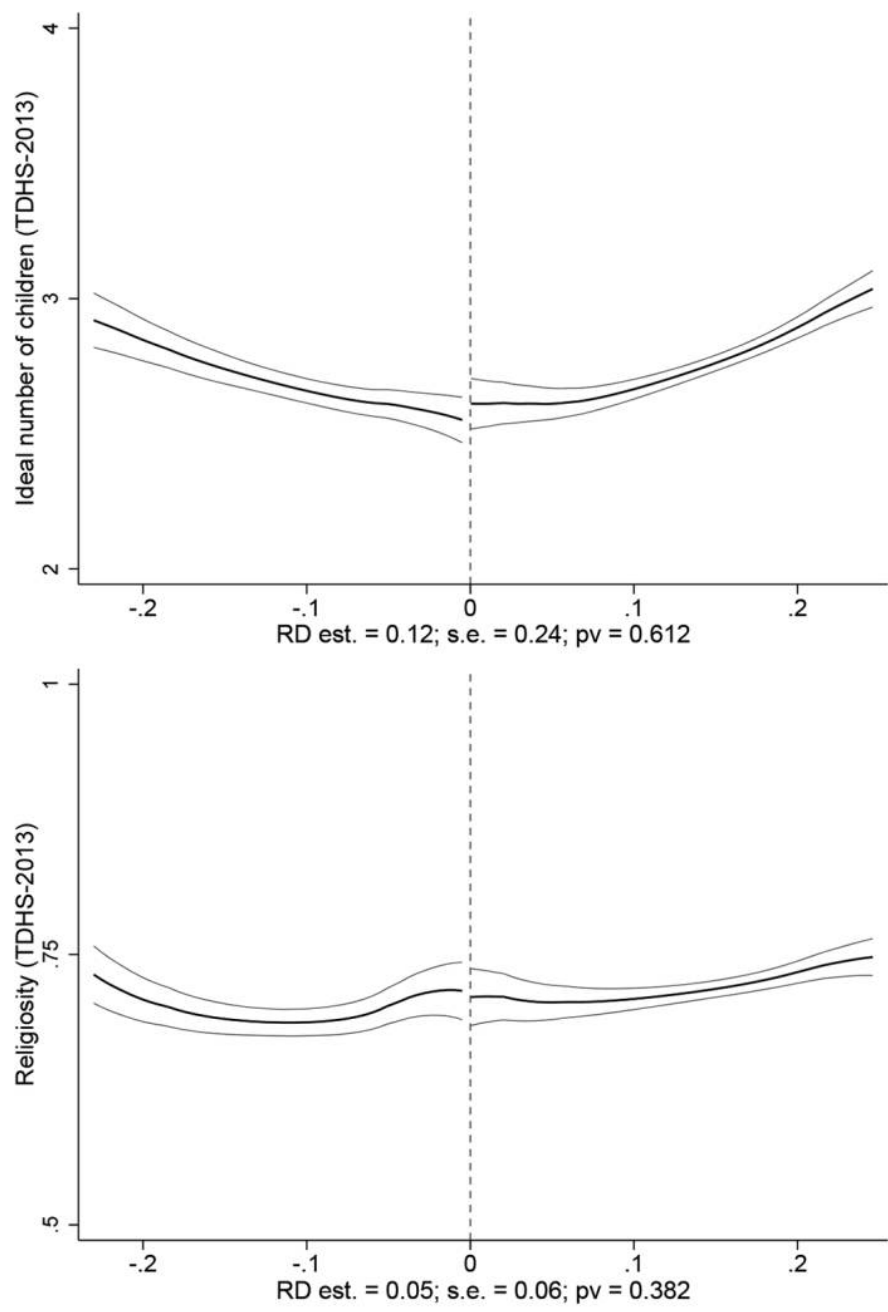

AK Parti province win margin 2004

FIG. 9. - Causal effect of Islamic governance in the province center on individual-level mediators TDHS-2013: ideal number of children and religiosity. Includes local polynomial smoothers (thick lines) with gray lines as confidence intervals. Local linear RD point estimates for KI optimal bandwidths, their robust SEs, and two-sided $P$-values are included below each panel.

the variance of the slope of the time variable $\left(\tau_{1}\right)$ is statistically significant. Moreover, the correlation between the slope of time and province-level random effects $\left(\tau_{01}\right)$ is negative and significant. This indicates that provinces with initially high fertility and marriage rates experience a steeper decrease. 
More important, however, the unemployment rate in a previous year is not associated with fertility and marriage in a given year. This rules out the second necessary condition for a potential pure economic pathway.

There is a positive and significant effect of the Quran course completion rate among men on both male and female marriage rates. The female course completion rate has no effect on any of the dependent variables. We should note that there is no multicollinearity between male and female Quran course completion rates (correlation coefficient is only .40). These results show that while an increase in male religiosity may increase marriage, it does not have any effect on fertility. Moreover, it is female religiosity, not male religiosity, that is causally influenced by local Islamic governance. In addition, recall that there is no effect of local Islamic governance on individual-level measures of religiosity. Consequently we conclude that the religiosity pathway does not account for the causal effect of local Islamic governance on marriage and fertility. Interestingly, the dummy indicator of the AK Parti rule in 2004 is statistically significant in M3, M6, and M9. While the effect sizes in M6 and M9 are similar to the RD estimates reported above (also see fig. 6), the effect size in M3 is smaller compared to the RD estimate for the effect of local AK Parti rule on GFR.

The province-level data on annual fertility and marriage rates enable us to test whether the causal effects of Islamic rule on our core independent variables vary over time. While we find that the effect on fertility decreases over time, this decrease is very small and statistically insignificant (interaction effect $=-.06, \mathrm{SE}=.04, P=.198$ ). But, the effect of Islamic governance on male and female marriage rates does decrease significantly between 2007 and 2014. For every year, the effect decreases by $0.36(\mathrm{SE}=.136, P=.010)$ for the male marriage rate and by about 0.32 for the female marriage rate (SE $=.152, P=.039)$. Recall that the original effect sizes were 3.82 for male marriage rates and 4.41 for female marriage rates. These effect sizes represent an average between 2007 and 2014, approximately centered around 2010 . We can then calculate roughly (assuming a constant rate of decrease) that the effect of Islamic governance on marriage will completely disappear by about 2020 .

\section{CONCLUSIONS AND DISCUSSION}

We tackled the long-standing question about the relationship among politics, religion, and family by focusing on a strategic research site: Turkey at the turn of the millennium, with the rise of the AK Parti into power. We built three complementary data sets, linking demographic, economic, and social data at the subnational level with election results. Using an RDD, we showed that local Islamic (AK Parti) rule in 2004 has had a positive and significant causal effect on fertility and marriage propensities in subsequent 


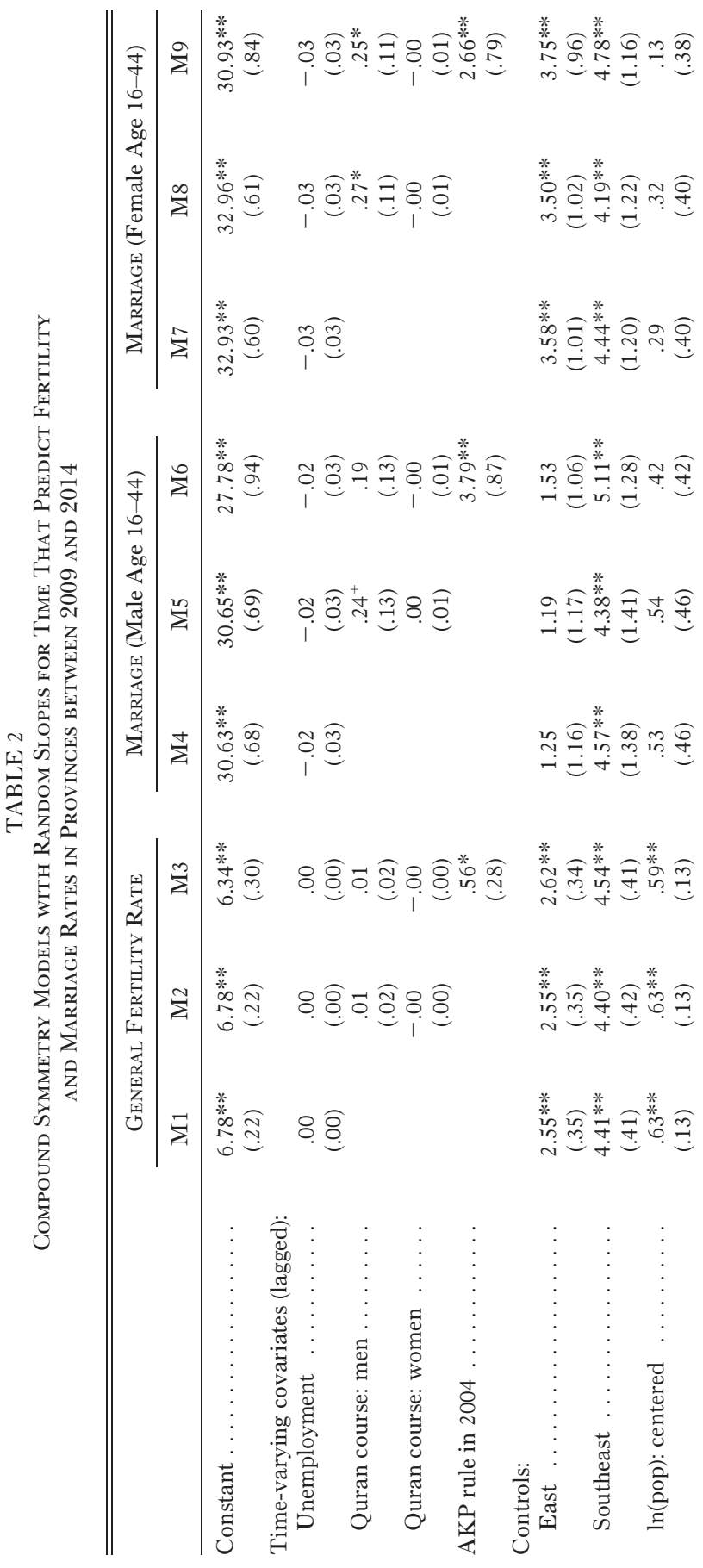

1334 


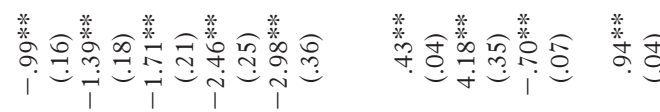

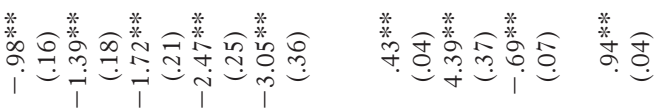

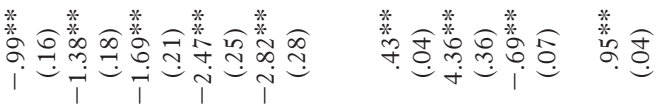

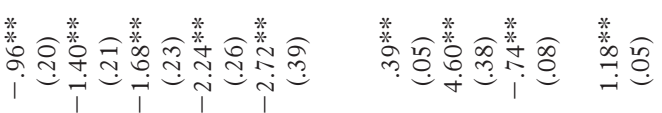

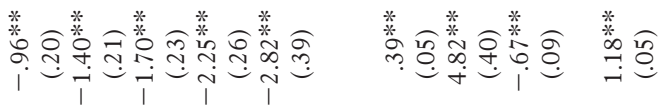

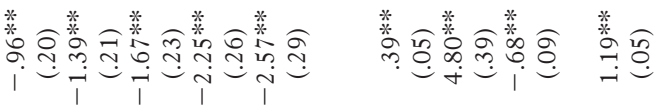

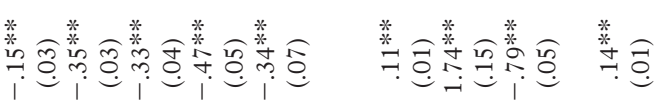

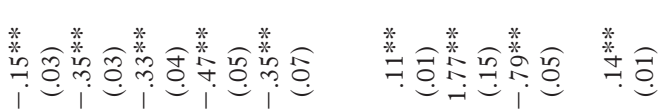

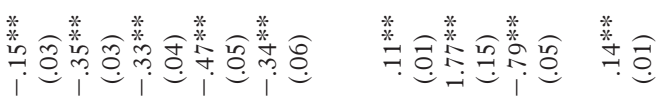

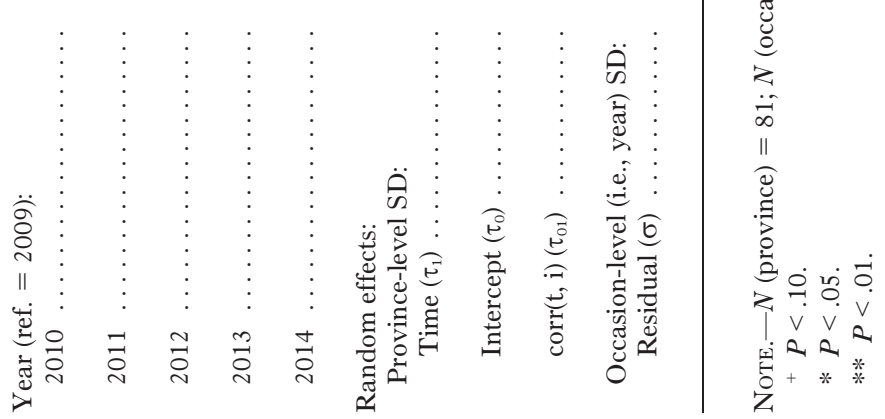


years. Our RDD compares the districts in which the AK Parti barely won with the districts the AK Parti barely lost. The districts on the two sides of the winning threshold are expected to be very similar in all observed and unobserved covariates, except for having a local Islamist mayor. In fact, we show that districts just below or above the winning threshold are indistinguishable when a number of important covariates including fertility rates and marriage prevalence before the elections are considered. Hence, our design implies a natural experiment in which an Islamic mayor is as-if randomly assigned to districts.

To explain these effects, we point to the massive wave of socioeconomic assistance the AK Parti has launched, which is distributed via local authorities, combined with a discourse that favors more traditional family behaviors and explicit pro-natalism. This socioeconomic assistance has targeted young families, mothers, and in general the poor. A number of analyses are consistent with this hypothesis. Our results are robust to alternative specifications of the RDD and are consistent across data sets. With additional data and analyses, we also exclude the possibility that the causal effect of local Islamic governance on marriage and fertility behavior is explained by economic development, by an increase in religiosity, by welfare migration, or by improvements in infant health.

There might be other potential mechanisms that we could rule out, if we had appropriate data. For example, the victory of the AK Parti in a district may have created an optimism about the future among its citizens, perhaps mainly among the marginalized Islamic circles. This optimism, in turn, may have resulted in more marriages and a higher fertility. Testing and identifying all potential causal pathways leading from AK Parti rule to higher fertility and marriage is beyond the scope of one article.

Our study contributes to the literature in multiple ways. First, from a political sociology perspective, it shows the significance of the deployment of strategic demography and local welfare policies. Strategic demography is significantly intersecting with the religious identity of Turkey's AK Parti. Our findings emphasize the importance of the role institutional and structural factors play, as opposed to individual norms and values, in shaping the link among religion, politics, marriage, and fertility. Second, from a social policy perspective, it shows the effects of a pro-natalist policy through local welfare provision on marriage and fertility, in an alla Turca model that is very different from pro-natalist strategies deployed in traditional Western democracies. The effects are somehow similar to Swedish pro-natalism but in a completely different setting and in a fashion that is designed to be compatible with the neoliberal agenda of the AK Parti. Third, from a demography perspective, we described the mechanisms through which Turkey's fertility transition halted at the replacement level, rather than shooting toward 
the much lower levels of its southern European neighbors or Iran. Fourth, our analyses showed the potential of RDDs in answering sociological questions and also in addressing the mechanisms behind the causal effects.

\section{REFERENCES}

Altık, Özlem. 2013. "Reproducing the Nation." Contexts 12 (2): 46-51.

Atasoy, Ylldı. 2009. Islam's Marriage with Neoliberalism: State Transformation in Turkey. Basingstoke: Macmillan.

Aytaç, S. Erdem. 2014. "Distributive Politics in a Multiparty System." Comparative Political Studies 47 (9): 1211-37.

Bellah, Robert N. 1958. "Religious Aspects of Modernization in Turkey and Japan." American Journal of Sociologv 64 (1): 1-5.

Bernardi, Fabrizio. 2014. "Compensatory Advantage as a Mechanism of Educational Inequality: A Regression Discontinuity Based on Month of Birth." Sociologv of Education 87 (2): 74-88.

Blaydes, Lisa. 2014. "How Does Islamist Local Governance Affect the Lives of Women?" Governance 27 (3): 489-509.

Bongaarts, John. 2006. "The Causes of Stalling Fertility Transitions." Studies in Familv Planning 37 (1): 1-16.

Bongaarts, John, and Griffith Feeney. 1998. "On the Quantum and Tempo of Fertility." Population and Development Review 24 (2): 271-91.

Breen, Richard, Seongsoo Choi, and Anders Holm. 2015. "Heterogeneous Causal Effects and Sample Selection Bias." Sociological Science 2:351-69.

Brooks, Clem. 2002. "Religious Influence and the Politics of Family Decline Concern: Trends, Sources, and U.S. Political Behavior.” American Sociological Review 67 (2): 191-211.

Buğra, Ayşe, and Çağlar Keyder. 2006. "The Turkish Welfare Regime in Transformation." Journal of European Social Policy 16 (3): 211-28.

Caughey, Devin, and Jasjeet S. Sekhon. 2011. "Elections and the Regression Discontinuity Design: Lessons from Close U.S. House Races, 1942-2008.” Political Analysis 19 (4): $385-408$.

Celik, Aziz. 2010. "Muhafazakar sosyal politika yonelimi: Hak yerine yardim yukumluluk yerine hayirseverlik" [New conservative social policy tendency on Turkey: Aid and philanthropy rather than social right and public responsibility]. I.U. Siyasal Bilgiler Fakultesi Dergisi [Journal of Istanbul University faculty of political sciences] 42:63-81.

Cleland, John, and Christopher Wilson. 1987. "Demand Theories of the Fertility Transition: An Iconoclastic View." Population Studies 41 (1): 5-30.

de la Cuesta, Brandon, and Kosuke Imai. 2016. "Misunderstandings about the Regression Discontinuity Design in the Study of Close Elections." Annual Review of Political Science 19:375-96.

Dodurka, Berra Zeynep. 2014. Turkiye'de merkezi devlet eliyle yapilan sosyal yardimlarcalisma raporu [Social assistance made through the central government in Turkey-a report]. Istanbul: Bogazici University.

Doğan, Eda. 2014. "Türkiye'de yoksulluğun ölçülmesi.” Thesis for Planning Expertise. Ministry of Development dissertation no. 2880, Ankara.

Eggers, Andrew C., Anthony Fowler, Jens Hainmueller, Andrew B. Hall, and James M. Snyder. 2015. "On the Validity of the Regression Discontinuity Design for Estimating Electoral Effects: New Evidence from Over 40,000 Close Races." American Journal of Political Science 59 (1): 259-74. 


\section{American Journal of Sociology}

Gangl, Markus. 2010. “Causal Inference in Sociological Research.” Anmual Review of Sociologv 36 (1): 21-47.

Gauthier, Anne H. 2007. "The Impact of Family Policies on Fertility in Industrialized Countries: A Review of the Literature." Population Research and Policv Review 26 (3): 323-46.

Gelman, Andrew, and Jennifer Hill. 2006. Data Analysis Using Regression and Multilevel/ Hierarchical Models. Cambridge: Cambridge University Press.

Goldstein, Joshua, Michaela Kreyenfeld, Aiva Jasilioniene, and Deniz Dilan Karaman Örsal. 2013. "Fertility Reactions to the 'Great Recession' in Europe: Recent Evidence from Order-Specific Data.”Demographic Research 29 (4): 85-104.

Goldstein, Joshua, Wolfgang Lutz, and Maria Rita Testa. 2003. "The Emergence of Subreplacement Family Size Ideals in Europe." Population Research and Policy Review 22 (5): 479-96.

Güriz, Adnan. 1971. "Türkiye'de Siyasi Partilerin Nüfus Politikası Konusunda Görüşleri” [Turkey's political parties' views on population policies]. Ankara Üniversitesi Hukuk Fakültesi Dergisi [Journal of the Ankara University faculty of law] 28:1-4.

Hacettepe University Institute of Population Studies. 2014. "2013 Turkey Demographic and Health Survey." Hacettepe University Institute of Population Studies, T. R. Ministry of Development, and TÜBİTAK, Ankara.

Hahn, Jinyong, Petra Todd, and Wilbert Van der Klaauw. 2001. "Identification and Estimation of Treatment Effects with a Regression-Discontinuity Design." Econometrica 69 (1): 201-9.

Imbens, Guido, and Karthik Kalyanaraman. 2012. "Optimal Bandwidth Choice for the Regression Discontinuity Estimator." Review of Economic Studies 79 (3): 933-59.

Imbens, Guido W., and Thomas Lemieux. 2008. "Regression Discontinuity Designs: A Guide to Practice." Journal of Econometrics 142 (2): 615-35.

Işik, Oğuz, and M. Melih Pinarcioğlu. 2006. "Geographies of a Silent Transition: A Geographically Weighted Regression Approach to Regional Fertility Differences in Turkey." European Journal of Population 22 (4): 399-421.

Johnson-Hanks, Jennifer. 2007. "Natural Intentions: Fertility Decline in the African Demographic and Health Surveys." American Journal of Sociology 112 (4): 1008-43.

Kagitcibasi, Cigdem, and Bilge Ataca. 2005. "Value of Children and Family Change: A Three-Decade Portrait from Turkey." Applied Psychology 54 (3): 317-37.

Kavas, Serap, and Arland Thornton. 2013. "Adjustment and Hybridity in Turkish Family Change: Perspectives from Developmental Idealism.” Journal of Familv Historv 38 (2): 223-41.

Kirk, Dudley. 1996. "Demographic Transition Theory.” Population Studies 50 (3): 361-87.

Koc, Ismet, Attila Hancioglu, and Alanur Cavlin. 2008. "Demographic Differentials and Demographic Integration of Turkish and Kurdish Populations in Turkey." Population Research and Policv Review 27 (4): 447-57.

Kocal, A. Vedat. 2014. "Bir sosyal politika ve siyasal meşruiyet araci olarak 'hayirseverlik': Türkiye'de sivil yardim organizasyonlarinin politik ekonomisi ve siyasal işlevi" ["Philanthropy" as a means of social policy and political legitimacy: The political economy and function of social assistance organizations in Turkey]. Paper presented at 6. Sosyal İnsan Haklari Ulusal Sempozyumu [the 6th National Social Human Rights Symposium]. Eskișehir.

Kohler, Hans-Peter, Francesco C. Billari, and José A. Ortega. 2002. "The Emergence of Lowest-Low Fertility in Europe during the 1990s." Population and Development Review 28 (4): 641-80.

Lee, David S., and Thomas Lemieux. 2010. "Regression Discontinuity Designs in Economics." Journal of Economic Literature 48:281-355.

Marshall, Emily A. 2015. "When Do States Respond to Low Fertility? Contexts of State Concern in Wealthier Countries, 1976-2011.” Social Forces 93 (4): 1541-66. 
McCrary, Justin. 2008. "Manipulation of the Running Variable in the Regression Discontinuity Design: A Density Test.” Journal of Econometrics 142 (2): 698-714.

McDonald, Peter. 2006. "Low Fertility and the State: The Efficacy of Policy." Population and Development Review 32 (3): 401-510.

McQuillan, Kevin. 2004. "When Does Religion Influence Fertility?” Population and Development Review 30 (1):25-56.

Mecham, R. Quinn. 2004. "From the Ashes of Virtue, a Promise of Light: The Transformation of Political Islam in Turkey." Third World Ouarterlv 25 (2): 339-58.

Merton, Robert K. 1987. "Three Fragments from a Sociologist's Notebooks: Establishing the Phenomenon, Specified Ignorance, and Strategic Research Materials." Annual Review of Sociology 13:1-29.

Metin, Onur. 2011. "Sosyal politika açısından AKP Dönemi: Sosyal yardım alanında yaşananlar" [Social policies of the AKP reign: The case of social aids]. Çalı̧̧ma ve Toplum Dergisi [Work and society] 1:179-200.

Meyersson, Erik. 2014. "Islamic Rule and the Empowerment of the Poor and Pious." Econometrica 82 (1): 229-69.

Morgan, S. Philip, and Myles G. Taylor. 2006. "Low Fertility at the Turn of the TwentyFirst Century." Annual Review of Sociology 32:375-99.

Morgan, Steven L., and Christopher Winship. 2007. Counterfactuals and Causal Inference: Methods and Principles for Social Research. Cambridge: Cambridge University Press.

Myrdal, Alva. 1941. Nation and Family: The Swedish Experiment in Democratic Family and Population Policy. New York: Harper.

Nichols, Austin. 2007. "Causal Inference with Observational Data." Stata Journal 7 (4): $507-41$.

2014. "RD: Stata Module for Regression Discontinuity Estimation." Statistical Software Components, Boston College Department of Economics.

Notestein, Frank W. 1945. "Population: The Long View." Pp. 36-57 in Food for the World, edited by Theodore W Schultz. Chicago: University of Chicago Press.

Özbudun, Ergun. 2006. "From Political Islam to Conservative Democracy: The Case of the Justice and Development Party in Turkey." South European Societv and Politics 11 (3-4): 543-57.

Pritchett, Lant H. 1994. "Desired Fertility and the Impact of Population Policies." Population and Development Revierw 20 (1): 1-55.

Snijders, Tom A. B., and Roel J. Bosker. 2012. Multilevel Analysis: An Introduction to Basic and Advanced Multilevel Modeling. London: Sage.

Teitelbaum, Michael S. 2015. "Political Demography: Powerful Trends Under-Attended by Demographic Science." Population Studies 69 (1): S87-S95.

Teitelbaum, Michael S., and Jay Winter. 1985. The Fear of Population Decline. Orlando, Fla.: Academic Press.

Thachil, Tariq. 2011. "Embedded Mobilization: Nonstate Service Provision as Electoral Strategy in India." World Politics 63 (3): 434-69.

Thistlethwaite, Donald L., and Donald T. Campbell. 1960. "Regression-Discontinuity Analysis: An Alternative to the Ex Post Facto Experiment." Journal of Educational Psvchology 51 (6): 309-17.

Thompson, Warren S. 1929. "Population." American Journal of Sociology 34 (6): 95975.

Turan, Illter. 2007. "Unstable Stability: Turkish Politics at the Crossroads?" International Affairs 83 (2): 319-38.

Weesie, Jeroen. 1999. "sg121: Seemingly Unrelated Estimation and the Cluster-Adjusted Sandwich Estimator." Stata Technical Bulletin 52:34-47.

Yavuz, M. Hakan. 1997. "Political Islam and the Welfare (Refah) Party in Turkey." Comparative Politics 30 (1): 63-82. 


\section{American Journal of Sociology}

2000. "Cleansing Islam from the Public Sphere." Journal of International Affairs 54 (1): 21-42.

Yavuzkanat, Pınar. 2013. "Türkiye'de illerin yoksulluk riskinin ölçülmesi üzerine bir yöntem önerisi." Thesis for Family and Social Planning Expertise. Ministry of Family and Social Planning dissertation. Ankara.

Yüksel, Yusuf. 2013. "In Search of a Pronatalist Population Policy for Turkey: A Gender Perspective." Presented at the Economic and Social Research Council seminar "Posttransitional Fertility in Developing Countries: Causes and Implications." Oxford. 